NBER WORKING PAPER SERIES

\title{
THE REORGANIZATION OF INVENTIVE ACTIVITY IN THE UNITED STATES DURING THE EARLY TWENTIETH CENTURY
}

\author{
Naomi R. Lamoreaux \\ Kenneth L. Sokoloff \\ Dhanoos Sutthiphisal \\ Working Paper 15440 \\ http://www.nber.org/papers/w15440
NATIONAL BUREAU OF ECONOMIC RESEARCH
1050 Massachusetts Avenue
Cambridge, MA 02138
October 2009

We would like to express our thanks to Oana Ciobanu, Shogo Hamasaki, Scott Kamino, and Ludmila Skulkina for their able research assistance, to Yun Xia for his help with programming, and above all to Shih-tse Lo for his comments and other assistance. We have also benefited from comments by Michael Darby, Rochelle Dreyfuss, Harry First, Paul Israel, Dan Kevles, Tom Nicholas, Ariel Pakes, Ross Thomson, Lynn Zucker, participants in seminars at the NYU Law School, UC Merced, and UCLA's Anderson School of Management, and members of the audience at the UCLA conference in honor of Kenneth Sokoloff in November 2008 and at the 2009 World Economic History Congress in Utrecht. We also gratefully acknowledge the financial support provided by the Social Sciences and Humanities Research Council of Canada (SSHRC), Le Centre interuniversitaire de recherche en économie quantitative (CIREQ) in Montréal, the Harold and Pauline Price Center for Entrepreneurial Studies at the UCLA Anderson School of Management, and the UCLA Center for Economic History. The views expressed herein are those of the author(s) and do not necessarily reflect the views of the National Bureau of Economic Research.

NBER working papers are circulated for discussion and comment purposes. They have not been peerreviewed or been subject to the review by the NBER Board of Directors that accompanies official NBER publications.

(C) 2009 by Naomi R. Lamoreaux, Kenneth L. Sokoloff, and Dhanoos Sutthiphisal. All rights reserved. Short sections of text, not to exceed two paragraphs, may be quoted without explicit permission provided that full credit, including $(\mathrm{C}$ notice, is given to the source. 
The Reorganization of Inventive Activity in the United States during the Early Twentieth

Century

Naomi R. Lamoreaux, Kenneth L. Sokoloff, and Dhanoos Sutthiphisal

NBER Working Paper No. 15440

October 2009

JEL No. N0,O3

\begin{abstract}
The standard view of U.S. technological history is that the locus of invention shifted during the early twentieth century to large firms whose in-house research laboratories were superior sites for advancing the complex technologies of the second industrial revolution. In recent years this view has been subject to increasing criticism. At the same time, new research on equity markets during the early twentieth century suggests that smaller, more entrepreneurial enterprises were finding it easier to gain financial backing for technological discovery. We use data on the assignment (sale or transfer) of patents to explore the extent to which, and how, inventive activity was reorganized during this period. We find that two alternative modes of technological discovery developed in parallel during the early twentieth century. The first, concentrated in the Middle Atlantic region, centered on large firms with in-house $\mathrm{R} \& \mathrm{D}$ labs and superior access to the region's rapidly growing equity markets. The other, located mainly in the East North Central region, consisted of smaller, more entrepreneurial enterprises that drew primarily on local sources of funds. Both modes seem to have made roughly equivalent contributions to technological change through the 1920s. The subsequent dominance of large firms seems to have been propelled by a differential access to capital during the Great Depression that was subsequently reinforced by the regulatory and military procurement policies of the federal government.
\end{abstract}

Naomi R. Lamoreaux

Department of Economics

UCLA

405 Hilgard Avenue

Los Angeles, CA 90095-1477

and NBER

lamoreaux@econ.ucla.edu

Kenneth L. Sokoloff

(deceased)
Dhanoos Sutthiphisal

McGill University

Department of Economics

855 Sherbrooke Street West

Montreal, Quebec H3A, 2T7

CANADA

and NBER

dhanoos.sutthiphisal@mcgill.ca 


\section{The Reorganization of Inventive Activity in the United States during the Early Twentieth Century}

According to the standard view of U.S. technological history, inventive activity was reorganized during the early twentieth century. Individuals had dominated the process of technological discovery during the preceding century, an era that the great historian Thomas Hughes has dubbed the golden age of the independent inventor (Hughes 1989). As the economy shifted from the mechanical technologies of the first industrial revolution to the science-based technologies of the second, however, the capital requirements (both human and physical) for successful invention soared. Large firms were better able to muster the resources needed to develop new technologies, and the inhouse research laboratories they built after the turn of the century enabled them, in the words of Joseph Schumpeter (1942), so completely to routinize the process of innovation that advances were realized "as a matter of course.” Although individual inventors never completely disappeared, they came to play a secondary role in technological change, as did the small entrepreneurial enterprises with which they were often associated.

There is, however, another literature that has very different implications for our understanding of trends in the location of innovative activity. This literature focuses on capital markets and portrays the early twentieth century as a period when more and more Americans were investing their savings in equities and, as a result, a broader range of companies could raise capital from the general public (see, for example, O’Sullivan 2007). The implication of this scholarship is that improved access to finance made it possible for small- and medium-sized enterprises (SMEs) to continue to make important 
contributions to technological discovery, even as the capital requirements for effective invention rose.

Until recently the technological history of the twentieth century has been written as if this second literature did not exist—as if the only story was the shift toward largefirm R\&D. The tide is now turning, and there are a growing number of studies questioning both the advantages of large firms' in-house research laboratories and whether the labs were ever really the dominant source of new technological discoveries. Thus far, however, the evidence offered in support of this revisionist view has been mainly anecdotal. The purpose of this article is to bring systematic evidence to bear on these questions, using data on the assignment (that is, sale or transfer) of patents.

In the next section of the paper we review the literature on the rise of large-firm R\&D, as well as recent studies that have led to a reassessment of the value of in-house research labs. We then survey the literature on equity markets and discuss its implications for understanding the reorganization of technological change during the early twentieth century. After a brief section describing our data sources, we move on to an investigation of whether the patterns in the assignment data are consistent with the view that large firms increasingly dominated the process of technological discovery. We find that large firms with industrial research labs obtained a rising share of patents during this period but that so did small entrepreneurial enterprises. Indeed, these two alternative modes of organizing technological discovery seem to have developed in parallel in different regions of the country. Large firms accounted for the lion's share of the inventions in the Middle Atlantic, though our evidence raises doubts about whether their ascendancy (at least during this period) owed much to their R\&D labs. By contrast, in 
the East North Central region smaller, more entrepreneurial enterprises predominated. To the extent that these latter firms benefited from the growth of financial markets, the relevant institutions seem to have been regional exchanges that drew primarily on local sources of capital. Although large firms would later come to dominate technological discovery, the change seems to have been more a function of the Great Depression and government policy than of the inherent superiority of in-house R\&D.

\section{The Literature on Large Firms' Industrial Research Labs}

Until the last decade or two, most economists and business historians would have agreed with Schumpeter (1942) that large firms had become the drivers of innovation in the U.S. economy. ${ }^{1}$ The avidity with which large firms built industrial research laboratories from the 1920s into the 1960s (see Mowery and Rosenberg 1989) certainly indicates that their executives thought the labs were a superior way of organizing technological discovery. Moreover, there seemed to be good theoretical reasons to believe they were right. In the first place, the electro-chemical technologies of the second industrial revolution were much more complex than the mechanical technologies of the first. Not only did successful invention require much greater investments in both physical and human capital, it required the kind of coordinated teamwork at which industrial research labs excelled. Second, inventors are better able, as a general rule, to solve production problems or create desirable new products if they have access to knowledge gained in manufacturing and marketing. Because this kind of knowledge is largely firm-specific, it is not easily acquired by outsiders, but it can readily be

\footnotetext{
${ }^{1}$ Examples from different parts of the literature include Jewkes, Sawers and Stillerman 1958; Chandler 1977; Hughes 1989; Lazonick 1991; Teece 1993; Cohen and Klepper 1996.
} 
transmitted to researchers in a firm’s own R\&D facilities. Third, in-house R\&D can solve the information problems that make it difficult for independent inventors to find buyers for their inventions and hence impede the commercialization of new technologies. Before buyers will invest in an invention, they need to be able to estimate its value- to assess, for example, the extent to which a new process will lower production costs, or whether a novel product is likely to appeal to consumers. But sellers of inventions have to worry that buyers will steal their ideas, so they may not be willing to reveal enough information about their discoveries to effectuate a sale. These problems can be avoided by moving the process of technological discovery in-house. ${ }^{2}$

Of course, there were always dissenters who argued that the value of in-house $R \& D$ for large firms was less a matter of efficiency than of market dominance through the control of important technologies (see, for example, Reich 1977, 1980, and 1985). There was also a large literature that questioned the relationship between firm size and innovation and suggested that most big businesses were considerably larger than the threshold at which size mattered (see, for examples, Scherer 1965 and Cohen, Levin, and Mowery 1987). However, it was not until the 1990s, when large firms began to cut back their R\&D expenditures and even shut down their labs, that scholars began seriously to question the idea that in-house R\&D was a superior way of organizing technological discovery (Rosenbloom and Spencer 1996). As some then pointed out, there were important information and contracting problems associated with the movement of R\&D in-house that were different from those that afflicted the market exchange of technological ideas but potentially just as troublesome. In order to learn about and gain

\footnotetext{
${ }^{2}$ For examples of scholars who have made these arguments, see Nelson 1959, Arrow 1962, Teece 1986 and 1988, Mowery 1983 and 1995, Hughes 1989, and Zeckhauser 1996.
} 
control of new technologies developed in their facilities, for example, firms had to invest in monitoring their employees’ activities and to create incentives that aligned employees’ interests with those of the firms. It was not easy, however, to design a reward structure that induced employees to work hard at generating new technological ideas without discouraging cooperation and the sharing of information within the firm (Lamoreaux and Sokoloff 1999). The problems of managing research employees were greatly magnified, moreover, when firms started hiring university trained scientists who wanted to raise their status in the academic community by publishing discoveries their employers would prefer to keep proprietary, and who were more interested in working on scientifically interesting problems than in improving their firm’s bottom line (Leslie 1980, Wise 1985; Smith and Hounshell 1985, Hounshell and Smith 1988). In addition, the informational advantages of locating $\mathrm{R} \& \mathrm{D}$ inside the firm turned out not to be as great as expected because research labs were often sited at a remove from the company's other facilities. It required considerable and continuous managerial effort to keep communication flowing across the different units of the firm (Hounshell and Smith 1988, Usselman 2007; Lipartito 2009).

At the same time as scholars were highlighting the problems faced by industrial research laboratories, they were also showing that the difficulties associated with transacting for technology in the marketplace were not as great as hitherto believed. Although patent rights are never perfectly enforced, they provide enough protection to enable inventors to engage in market exchange. Moreover, the information problems that afflict this kind of trade can be solved in a number of ways. Firms seeking to purchase outside technologies can invest in facilities for assessing them and can work to cultivate a reputation for safeguarding inventors’ interests; intermediaries who possess the trust of 
parties on both sides of the market can take charge of facilitating exchange; and talented inventors can establish track records that give buyers confidence in the worth of their discoveries (Gans and Sterns 2003; Lamoreaux and Sokoloff 1999 and 2007). Naomi Lamoreaux and Kenneth Sokoloff (1996, 2001, and 2003) demonstrated that a vibrant trade in patented inventions developed during the second half of the nineteenth century, intermediated by patent agents and lawyers, that enabled talented independent inventors to specialize in technological discovery. Steven Usselman (2002) and Stephen Adams and Orville Butler (1999) provided examples of firms that built reputations that encouraged inventors to bring them their ideas. Ashish Arora, Andrea Fosfuri, and Alfonso Gambardella (2001) documented the revival of trade in patented technology in high tech industries in the late twentieth century. Moreover, scholars have uncovered considerable evidence that large firms continued to purchase inventions from outsiders even after they created industrial research laboratories. Indeed, David Mowery (1995) has shown that the original function of most in-house R\&D facilities was to keep abreast of (and vet for purchase) externally generated technology (see also Lamoreaux and Sokoloff 1999 and 2007). Tom Nicholas (2009) has used geo-coded data on the location of inventors and research labs to show that a significant fraction of the most valuable patents acquired by large firms during the 1920s were most likely not generated in the firms’ research laboratories. Eric Hintz (2007) has provided case-study evidence showing that, even in the heyday of the industrial research lab in the 1950s, large firms transacted for important technologies with outside inventors who insisted on maintaining their independence. 


\section{The New History of Equity Markets}

If the 1920s was the decade when large firms first began to build industrial research laboratories in significant numbers, it was also the decade when securities markets began to channel funds to firms on the technological cutting edge. To the extent that the recipients of these funds were the very same enterprises that were building inhouse $R \& D$ facilities, the history of the growth of equity markets would simply reinforce the standard view that large firms were the main drivers of innovation in the twentieth century. But recent research has shown that small entrepreneurial enterprises also obtained access to equity markets during this period, a development that is not consistent with the dominant narrative of American technological history.

During the nineteenth century trading on the markets was pretty much limited to the securities of banks, railroads (bonds, not equities), other transportation companies, and utilities (Navin and Sears 1955; Cull, et al. 2006). The number of industrials whose securities were listed on the New York Stock Exchange could be counted on one's fingers, and the number whose unlisted securities traded in New York was also very low (Baskin and Miranti 1997). Industrials had a greater presence on regional exchanges such as Boston’s, but even there their shares traded only infrequently (Martin 1898). The general view among scholars is that problems of asymmetric information limited the public’s appetite for equities. Markets were unregulated, firms reported little information about their affairs, and insiders manipulated both the flow of information and corporate decisions to their advantage (De Long 1991, Baskin and Miranti 1997, White 2003). Even the savvy could get taken, as Commodore Vanderbilt found when officers of the 
Erie Railroad responded to his attempt to buy control by cranking up the printing press and turning out more and more new shares of Erie stock (Adams 1869).

By the turn of the century, however, private parties with an interest in expanding the reach of the securities markets were taking steps to increase the confidence of investors. For example, the New York Stock Exchange instituted a rule change in 1896 requiring firms listed on the exchange to publish audited balance sheets. A few firms had already begun to provide this kind of information on their own, but the new rule helped to make the exchange an imprimatur of quality, increasing trading, the value of listed shares, and not coincidentally, the price of a seat on the exchange (Neal and Davis 2007). At the same time, investment bankers such as J. P. Morgan exploited the reputations for probity they had built up over the years to expand the market for specific securities. Morgan had worked out a technique for building investors’ confidence when he reorganized bankrupt railroads during the 1890s, putting his own people on the boards of directors to reassure stockholders that the business would be run in their interests (Carosso 1987). The railroads' return to profitability enhanced his reputation, and Morgan used the same method to promote the securities of the giant consolidations he orchestrated at the turn of the century. Studies by J. Bradford De Long (1991) and Miguel Simon (1998) suggest that stockholders responded by flocking to buy the securities of “Morganized” firms and also profited handsomely from their purchases.

This record of profitability whetted investors' appetites for securities, but it was not until the 1920s that the market really took off. Investment bankers had developed new techniques during World War I to sell Liberty Bonds. With the return of "normalcy" in the 1920s, they applied what they had learned to the sale of equities. Eager to enter 
this business, commercial banks circumvented laws that prevented them from dealing in stocks by setting up affiliates to sell securities to their customers. At the same time, enterprising financiers brought large numbers of small investors into the market for the first time by creating new investment vehicles that gave them access to diversified portfolios. The most important of these, the investment trust, served much the same purpose as mutual funds do today (Carosso 1970; White 1984 and 1990; De Long 1991; O’Sullivan 2007). Sales were also fueled during this period by competition between the NYSE and the New York Curb Exchange (which, like the NASDAQ more recently, specialized in issues of newer firms in technologically dynamic industries), by the growth of regional exchanges such as Cleveland's (which promoted the securities of local enterprises), and by the development of a national network of dealers that sold securities “over the counter” (O’Sullivan 2007; Lamoreaux, Levenstein, and Sokoloff 2006 and 2007; Federer 2008).

As investors lapped up what the bankers initially had to offer, firms began to issue more and more new securities. Mary O’Sullivan (2007) has shown that the number and size of new corporate stock issues soared in the early twentieth century, reaching levels during the late 1920s that in real terms were not attained again until the 1980s. Even if one leaves out the bubble years of 1928 and 1929, issues were higher as a proportion of GDP during the 1910s and 1920s than in any other period of American history except the recent dot-com boom. Moreover, the great bulk of the issues consisted of common stock, with investors seeking to profit as much or more from a run-up in share prices as from dividend payments. 
It might be thought that the primary beneficiaries of this growth in the securities markets would be large, well-established firms for the simple reason that investors could readily gather information about them (Calomiris 1995). Certainly, as Tom Nicholas (2003, 2007, and 2008) has shown, during the 1920s investors particularly favored the equities of large firms with R\&D facilities and substantial portfolios of patents in cuttingedge technologies (see also White 1990). But this appetite for technology stocks seems to have spilled over to smaller firms as well. The most obvious evidence is the enormous expansion in the number of firms about which the financial press reported information. Whereas only a handful of industrials were even mentioned in the pages of the Commercial and Financial Chronicle in the 1890s, during the late 1920s Moody's devoted more than three thousand pages of its annual securities manual to financial information on individual industrial enterprises. O'Sullivan (2007) has shown that investors were particularly attracted to new firms in "high-tech" industries such as radios and aviation. The advent of commercial broadcasting stimulated a craze for radio stocks during the early 1920s that led to so many initial public offerings (IPOs) that wags estimated the number of new shares to be about equal to the number of radios sold. Similarly, after Charles Lindbergh’s transatlantic flight captivated the public’s imagination, soaring interest in aviation stocks elicited about 125 additional offerings of securities, many of them from new entrants to the industry. O'Sullivan has calculated that the medium age of the issuers was only 0.4 years! Most of the new securities promoted during the 1920s were not listed on the NYSE, but were instead traded on regional exchanges, on the curb market, over the counter, or through more informal channels. 
The implication of the literature on the growth of equity markets is that SMEs on the technological cutting edge were increasingly able to tap into broader capital markets to finance their inventive activities. This implication, however, is difficult to square with the standard argument that industrial research laboratories had already begun to displace entrepreneurial enterprises as a locus of technological discovery by the late 1920s. In the rest of the paper we bring systematic evidence to bear on this problem. Our aim is to determine whether there was a reorganization of technological discovery during the early twentieth century in favor of large firms, or whether SMEs (and perhaps also independent inventors) continued to play an important role in the generation and exploitation of new technologies.

\section{Data Sources}

We approach this problem through the analysis of patent data. ${ }^{3}$ The starting point for our analysis is four random cross-sectional samples of patents that we drew from the Annual Reports of the Commissioner of Patents for the years 1870-71, 1890-91, 1910-11, and 1928-29. ${ }^{4}$ For each patent in the samples we recorded a brief description of the invention, the name and location of the patentee(s), and the names and locations of any

\footnotetext{
${ }^{3}$ We recognize that some scholars would object that large firms often eschewed patenting in favor of secrecy, taking advantage of the new legal protections for trade secrets that emerged in the early twentieth century (Fisk 2001), but we see no reason to assume a priori that large firms were more likely to favor secrecy than small firms. Indeed, economists working on late twentieth-century data have sometimes found precisely the opposite. Using survey data, they have shown, for example, that small enterprises worry that they will be not be able to protect their intellectual property against infringement by large firms - that they will be for all practical purposes defenseless against giants with the resources to hire the best legal talent (Lerner 1995; Cohen, Nelson, and Walsh 2002; Arora, Ceccagnoli, and Cohen 2007). Some scholars might also object that large firms devoted a significant proportion of their R\&D resources to systematizing and elaborating new technologies in ways that often were not patentable (see Usselman 2002 on the railroads, for example). That may well have been the case, but our primary aim in this paper is to understand whether large firms with R\&D facilities were the dominant source of new technological discoveries by the late 1920s.

${ }^{4}$ The 1870-71 sample amounts to about 6 percent of total patents; the other samples about 4 percent.
} 
assignees who obtained rights to the invention before the patent was actually issued. We then linked the patents to other information we collected on the assignees to whom the patentees transferred their patent rights. For example, we looked up each company that received a patent in the directories of industrial research laboratories compiled by the National Research Council (NRC). We also collected information about companies receiving patents from financial publications: the Commercial and Financial Chronicle for the 1870-71 and 1890-91 cross-sections; Poor's Manual of Industrials for 1910-11; and Moody's Manual of Investments for 1928-29. Finally, we looked up both individual and company assignees wherever possible in city directories.

The information we obtained from these financial publications and city directories enabled us to classify a large number of the companies who obtained patents by size, measured in terms of the firms' total assets (or in a few cases where that information was not available, total capitalization). We were also able to determine for a large number of firms whether the inventor was an officer, director, or proprietor of the company to which he (or in rare cases she) assigned the patent. Our basic strategy was to use this information to look for changes over time in the relationship between patentees and their assignees and in the types of companies obtaining assignments. Were inventors increasingly less likely over time to be principals in the firms obtaining their patents? Were they more likely to be employees? Was there a shift over time in the types of firms obtaining assignments toward very large firms or toward firms with in-house research laboratories? 


\section{The Organization of Inventive Activity before the Great Depression}

If there was a reorganization of inventive activity during the early twentieth century in favor of large firms with their own R\&D facilities, one would expect to find, first of all, that inventors were assigning an increasing proportion of their patents to companies by the time of issue (because employees typically had to transfer their patents automatically to their firms), ${ }^{5}$ and second, that large firms with research labs would account for a growing proportion of patent assignments. Certainly, the evidence bears the first expectation out. As Table 1 shows, the fraction of patents assigned at issue increased quite steeply over time, rising from 16.1 percent in the $1870-71$ cross section to 56.1 percent in 1928-29, with 87.2 percent of assignments at issue in the latter sample going to companies. The proportion of patents that went to large companies also increased dramatically. For the 1928-29 cross section, the proportion assigned to enterprises reported by Moody’s as having assets of at least \$10 million was 20.5 percent, and 16.1 percent went to companies in that category listed by the NRC as having industrial research laboratories. ${ }^{6}$

These last figures represented a significant increase over those for 1910-11, when few large firms had labs and the proportion of patents that went to firms with more than \$10 million in assets was only 3.4 percent. The question, however, is whether the 192829 numbers are large enough to make the case that such enterprises were coming to

\footnotetext{
${ }^{5}$ Contracts requiring employees to assign all patents to their employers became increasingly prevalent by the 1920s. See Fisk (1998) and Lamoreaux and Sokoloff (1999).

${ }^{6}$ It is important to bear in mind that assignments to companies can come from outside inventors as well as from employees, so our figures overestimate the proportion of patents generated by the firms concerned. Our analysis includes only utility patents granted to residents of the United States. Adding patents awarded to foreigners would not change the analysis because there were so few of them. Even in 1930, there were only about 40 in the sample, and intriguingly, somewhat more of them were acquired by firms not reported in Moody's than by large firms. We also exclude from the analysis the small number of patents that were assigned to foreign companies and the small number of patents that were reissued.
} 
dominate the process of technological discovery. Over the same period, the proportion of patents assigned to companies not covered by publications like Moody's also rose-from 13.5 to 22.1 percent. The latter number is slightly larger than the proportion of patents that went to large firms in the same year, so it would seem that small firms were holding their own as generators of patentable technology.

There was also a dramatic increase between 1910-11 and 1928-29 (from 4 to 9 percent) in the share of patents acquired by firms where the patentee was an officer, director, or proprietor or that bore the patentee's surname (Table 2, Panel A). ${ }^{7}$ We presume that these firms were formed to exploit a technology invented by the patentee and so treat the existence of a patentee-principal as sign of the entrepreneurial character of the company. Sometimes the patentee was clearly the moving force behind the enterprise and held a position (such as president or secretary/treasurer) that indicated his active involvement in running the business. Sometimes another person played the role of entrepreneur, and the patentee received an ownership interest and a largely honorific title (such as vice president) in order to ensure his continuing participation in developing and improving the technology.

As Table 2 indicates, there was relatively little overlap between the firms we are defining as entrepreneurial and the large firms covered by Moody's, particularly those that NRC surveys indicated had industrial research labs. In 1928-29 only 4 percent of the assignments to large firms with $R \& D$ labs involved patentee-principals, as opposed to 26

\footnotetext{
${ }^{7}$ Information on directors' identities comes from city directories and from financial publications such as Moody's. Our figures understate the number of patents awarded to principals of firms because we are not able to identify the officers and directors of small companies located in areas without city directories. Our figures are also underestimates because we miss companies with inventor-principals in which the inventor did not happen to receive a patent in 1928 or 1929. Some of the increase we observe may simply be a result of the growth in the number of firms covered by national financial publications. It is doubtful, however, whether this expansion in coverage explains much of the change because relatively few of the firms for which financial reports are available actually had patentee principals.
} 
percent of the assignments to firms in the "other" category. Moreover, from Table 3 we can see that fully 66.3 percent of the assignments by patentee-principals went to "other" companies and only 7.1 percent to large firms with R\&D labs. The "other" category consists of firms for which we were not able to find reports in Moody's, which we assume means that they were generally much smaller in size than those that for which there were published financial reports. Yet another striking difference between the entrepreneurial firms and the large-scale enterprises found in Moody's is that they tended to be located in different parts of the country. Whereas large firms were disproportionately concentrated in the Middle Atlantic region, enterprises in which the patentee was a principal were more likely to be found in the East North Central states (Table 4 and Table 6). Hence in 1928-29, 53.5 percent of the patents acquired by large firms went to assignees located in the Middle Atlantic and only 29.0 percent to those in the East North Central region. By contrast, 43.9 percent of the patents assigned by patentee-principals went to firms in the East North Central states and only 23.5 percent to those in the Middle Atlantic. ${ }^{8}$

The Middle Atlantic and the East North Central regions were the nation's two main technology centers by the late 1920s, each accounting for roughly one third of total patents (Table 4). The two regions had comparable rates of patenting per capita (Figure 1) and similar overall rates of assignment (Table 5). In both, moreover, large firms obtained a greater share of assignments in 1928-29 than they had in 1910-11.

Nonetheless, to the extent that there was a reorganization of inventive activity in favor of large-firm R\&D during this period, the change seems to have gone a lot further in the Middle Atlantic region than in the East North Central. In the former 32.5 percent of all

\footnotetext{
${ }^{8}$ On this point, see also Lamoreaux and Sokoloff 2009.
} 
patents went to large firms and only 19.5 percent to "other” companies in 1928-29; in the latter the proportions were reversed, with 19.7 going to large firms and 27.5 to "other" companies (Table 5). Moreover, the proportion of assignments that went to entrepreneurial firms (that is, to firms where the patentee was a principal) was more than twice as high in the East North Central as in the Middle Atlantic (Table 5). Rather than a complete reorganization of technological discovery, therefore, the data suggest that two alternative modes of organizing technological discovery coexisted during the early twentieth century. Large firms may have dominated in the Middle Atlantic, but the East North Central continued to spawn significant numbers of entrepreneurial startups.

\section{Questions of Importance and Technological Sector}

Before one can conclude definitively that two alternative modes of technological discovery coexisted during the early twentieth century, one must consider the possibility that the patents assigned to entrepreneurial firms were on the whole less significant than those acquired by large firms with R\&D labs. After all, patent counts can be notoriously misleading because they weigh equally inventions that are of fundamentally different importance. One must also consider the possibility that entrepreneurial firms operated in different technological sectors than large firms with R\&D labs-that is, that the patents they acquired were less "high tech.”

The question of importance is difficult to resolve for the early twentieth century because patents were not subject to renewal fees and it was not yet common practice for inventors to cite prior art in their applications. We employ two alternative, but unfortunately highly imperfect, measures to assess whether the patents assigned to large 
firms were generally more significant than those assigned to their entrepreneurial counterparts. First, following Nicholas (2003), we use information on whether or not a patent in our sample was cited much later on (by a patent granted between 1975 and 2002). Second, we collect information on the number of claims allowed in the patent grant (Lerner 1994; Lanjouw and Schankerman 2004).

As Table 2 (Panel B) shows, the first measure does not favor large firms with industrial research laboratories. Only 25 percent of the patents assigned at issue in 192829 to this type of firm were cited by a patent granted between 1975 and 2002, whereas the proportion for firms not included in Moody's was 32 percent. $^{9}$ This result, however, may not be all that surprising. We know that large firms like the American Telephone and Telegraph Company (AT\&T) patented virtually all the inventions devised by their employees, whether important or not, for morale reasons and because even minor patents could be useful for blocking rivals' incursions in their markets (Lamoreaux and Sokoloff 1999; Reich 1977, 1980, and 1985). Even in absolute terms, however, large companies with R\&D laboratories accounted for a much smaller proportion of patents cited after 1975 than did firms in the "other" category: 12.2 versus 21.8 percent (see Table 3, panel B). Intriguingly, patents that were not assigned at issue accounted for almost half (48.3) of those cited after 1975 (Table 3) and had a higher probability of being referenced by late-twentieth-century patents (36 percent) than those in any of the other assignment categories (Table 2). The explanation may be that inventors sought to maintain control of their most valuable discoveries in order to profit more from exploiting them. This possibility fits with work by Lamoreaux, Margaret Levenstein, and Sokoloff (2006 and

\footnotetext{
${ }^{9}$ None of our results change when we use the number of later citations as a measure of importance rather than simply whether or not the patent was ever cited.
} 
2007) showing that important inventors in the Cleveland region often had considerable bargaining power vis-à-vis their financial backers and that they exercised that power by licensing rather than assigning their patent rights to their companies.

Regression analysis of the 1928-29 sample confirms the descriptive finding that the patents acquired by large firms with $R \& D$ labs were no more likely to be cited by late-twentieth-century patents than those acquired by "other" firms. To keep the focus on the different types of enterprises, we restrict our attention to patents assigned at issue to companies. ${ }^{10}$ The dependent variable is a dummy that takes a value of one if the invention was cited by a patent awarded in 1975-2002. The independent variables include dummies for the size category of firms in terms of total assets (the omitted category is firms for which we have no financial information ${ }^{11}$ ), whether the NRC listed the firm as having an industrial research lab, whether the inventor was a principal of the firm, the region in which the assignee was located (the omitted category is the Middle Atlantic), and whether the patent was in a high-tech industry for the time. We use two alternative definitions of high-tech. The first (high-tech1) is based on our reading of the text of the patent. It defines patents in the following industries as high-tech and all others as not: electrical machinery and products, chemicals, petroleum, plastics and rubber, automobiles, primary metals, mining machinery, and transportation equipment, as well as the machinery used in production in these industries. The second (high-tech2) defines as high-tech patents that were classified by Hall, Jaffe, and Trajtenberg (2002) as falling in technology subclasses 11-49 (based on the U.S. Patent and Trademark Office’s

\footnotetext{
${ }^{10}$ The results in Table 7 do not change when we run the estimations on all patents, except that the coefficients on the dummy for high-tech in the first two estimations become consistently negative and weakly significant.

${ }^{11}$ This category includes firms for which Moody's did not include information on assets or capital, as well as firms that Moody's did not cover.
} 
classification scheme): chemicals, computers and communication technology, drugs and medical devices, and electrical and electronics. The estimations are probits, and the reported figures are the marginal effects of changes in the independent variables.

As the first four columns in Table 7 show, none of the coefficients is statistically significant. $^{12}$ Patents assigned to firms with more than $\$ 10$ million in assets were no more likely to be cited at the end of the century than those that went to firms not included in Moody's, and firms with R\&D labs were no more likely to acquire patents that would be cited later than those without. Indeed, the point estimates suggest that patents acquired by large firms with R\&D labs were somewhat less likely to be cited. We obtained the same results when we included dummies for the individual technology subclasses that make up high-tech2 (not shown). In other words, even within subclasses, the patents of large firms with R\&D labs were no more likely to be cited later on than those of small firms. ${ }^{13}$ Nor were there any significant regional differences in the frequency of citations. Patents assigned to firms in the Middle Atlantic were no more nor less likely to be cited than those assigned to firms in the East North Central region. Regardless of how we define high-tech, moreover, patents in the cutting-edge industries of the time were no more likely to be cited than other patents, and most of the point estimates have the wrong sign.

This last result in particular raises the question of whether citations from a much later period are a good measure of importance. It is at least possible that technology was changing more rapidly in high-tech industries than in low-tech ones, making inventions in the former obsolete more quickly and thus less likely to be relevant to patents granted

\footnotetext{
${ }^{12}$ Including interactions between the R\&D and size variables does not change the result. We do not report these estimations, however, because of serious problems of multicolinearity.

${ }^{13}$ We do not report these results because of small cell sizes.
} 
in the late twentieth century. For example, Lee de Forest’s patents for amplifiers were unquestionably important at the time, but because the devices used vacuum-tube technology they were not cited after $1974 .{ }^{14}$ On the other hand, one could argue that patents in old industries circa 1930 were even more likely to be irrelevant by the late twentieth century and hence still less likely to be cited.

Because of our doubts about the validly of late-twentieth-century citations as an indication of a patent's importance, we collected data for an alternative measure that has been suggested in the literature- - the number of claims allowed in each patent grant (Lerner 1994; Lanjouw and Schankerman 2004). The estimations (here negative binomial regressions) are reported in Table 7, columns 5 through 8 . Large firms had more claims per patent than those not covered in national financial publications, which by this measure would seem to indicate that large firms’ patents were more important on average than those obtained by small firms. Another interpretation, however, is that large firms had superior access to legal expertise and thus were able to secure approval for more claims during the examination process. ${ }^{15}$ Regardless, patents acquired by firms that had $R \& D$ labs were not more important by this measure than those acquired by firms that did not; the point estimates have the wrong sign and are weakly significant in the first two specifications. Moreover, the negative coefficients on the high-tech dummies (weakly significant for the second of our two classification schemes) raise doubts about the validity of the number of claims as a measure of importance, just as they did for latetwentieth-century citations.

\footnotetext{
${ }^{14}$ We searched in Google patents for de Forest's patents that included the word "vacuum." Unlike de Forest's other patents, none of these were cited in the late twentieth century.

${ }^{15}$ When we presented this paper at the NYU Law School, faculty and students in the audience were skeptical that the number of claims reflected anything but the skill of the patent lawyer.
} 
As for the question of whether the patents acquired by large firms with industrial research laboratories were more likely to be in high-tech industries than those acquired by firms operating below the financial radar screen, the answer is yes. For the years 1928-29, fully 78 percent of the patents acquired by the former were in high-tech industries according to our first definition and 46 percent according to our second (Table 2, Panels C and D). The figures for firms not found in Moody's were only 52 percent and 21 percent respectively. As the probit regressions in Table 8 show, by our first definition both large firms and firms with R\&D labs were significantly more likely to acquire hightech patents than firms without financial reports in Moody’s. By our second measure, however, only firms with R\&D labs were significantly more specialized in cutting-edge technology. The point estimates for entrepreneurial firms were negative, though not significant, in all of the regressions. Finally, firms in the Middle Atlantic, where most of large enterprises with industrial research labs were located, were generally more likely to acquire high-tech patents than were firms in other regions, including the East North Central, and the differences were particularly apparent for our second measure.

Before one leaps to the conclusion that large firms with industrial research laboratories were dominating inventive activity in the high-tech sectors of the economy by the late 1920s, it is important to note that firms not included in Moody's still accounted for a substantial proportion of high-tech patents: 22.7 percent of the total for high-tech1 and 19.3 percent for high-tech2, compared respectively to 24.8 and 30.7 percent for large firms with R\&D labs (Table 3, Panels C and D). So did firms in the East North Central: 32.0 percent for high-tech 1 and 27.3 percent for high-tech2, compared respectively to 38.0 and 42.0 percent for the Middle Atlantic (Table 4, Panel B). 
Moreover, it is important to note that large firms were disproportionately high-tech as early as 1910-11, when few of them had R\&D labs. Indeed, in 1910-11 large firms without R\&D labs were much more likely to acquire high-tech patents than the firms that pioneered in establishing in-house research facilities (Table 2, Panels C and D). Furthermore, it is not at all clear how many of the patents acquired by large firms with R\&D facilities actually originated in the companies’ labs. For the 1928-29 cross section, 36.9 percent of the patents assigned to large firms with research labs came from patentees who were located in a completely different state from any of their assignees’ labs. ${ }^{16}$ This result is somewhat larger than that of Nicholas (2009), who also found that a significant fraction of patents acquired by a sample of large firms came from inventors who resided beyond commuting distance from the firms' labs. ${ }^{17}$ It is also consistent with the argument (Mowery 1995, Lamoreaux and Sokoloff 1999) that the reason that many firms established R\&D labs in the first place was to improve their ability to assess inventions offered for sale by outside inventors. To give one example, at the end of World War I Standard Oil of New Jersey founded its first research department on the principle that "new ideas and inventions ... would arise in the main from external sources, and that [the department's] primary job ... would be to uncover these ideas, test them out, and carry

\footnotetext{
${ }^{16}$ Adding a variable for whether the patentee resided in the same state as one of the company's labs does not change the estimations in Tables 7 or 8 . The variable was never significant, though intriguingly the point estimates suggest that patents by inventors located in the same state as a lab were less likely to be cited than those by inventors who resided in other states.

${ }^{17}$ Nicholas found that a quarter of the inventions assigned during the 1920s to 69 large firms operating 94 industrial research labs came from inventors who resided beyond commuting distance of the labs. Nicholas also found that the patents obtained from distant inventors were substantially more important on average (more likely to be cited by late twentieth century patents) than those acquired from inventors who lived within commuting distance. In the case of the General Electric Company (GE), Nicholas was able to check his list of inventors against employment records and found that about a fifth of the patents GE acquired came from inventors who were not employees.
} 
them forward to some practical end”-not, as has been generally assumed, to foster “primary research” (Gibb and Knowlton 1956).

Finally, our data enable us to test one of the arguments that scholars have offered for the superiority of research laboratories - that they facilitated the teamwork required for effective innovation in the complex, science-based technologies of the second industrial revolution. If we take the presence of multiple inventors on a patent to be an indication of teamwork, we find that large firms, even those with industrial research laboratories, had only slightly more of it. Fourteen percent of the patents acquired by large firms with R\&D facilities were granted to more than one inventor, as opposed to 10 percent of those acquired by firms not included in Moody’s (Table 2, panel E). That difference, however, is not statistically significant, as the regressions in the last four columns of Table 8 show. ${ }^{18}$

To recap the results thus far, by the 1920s there seen to have been two main regions of inventive activity in the U.S., each organized along different lines. In the Middle Atlantic, large firms with in-house R\&D facilities predominated, whereas the East North Central was characterized by entrepreneurial startups. Assignments to large firms with R\&D facilities accounted for an increased proportion of patents by the late 1920s, but assignments to firms without access to national capital markets represented a larger (and still growing) share of patents. Moreover, it is by no means clear that the patents acquired by large firms with research labs were more important than those

\footnotetext{
${ }^{18}$ There may have been some bias against filing joint patents because they could pose special legal difficulties. For example, in cases where establishing priority was critical, the date of the invention could not precede the date when the inventors first started working together. Nonetheless, patents for inventions that were the joint product of more than one inventor were invalid unless all the inventors were named in the patent, and firms with R\&D laboratories would have had to be very careful on this point. By the 1920s, moreover, the courts were no longer penalizing inventors who inadvertently, without fraudulent intent, mistakenly listed a joint inventor on a patent. See Robb 1922, 113-114; and Robinson 1890, I, 561-73.
} 
acquired by firms in other categories. Large firms' patents were, if anything, less likely to be cited by late-twentieth-century patents than those of other firms, and though they included more claims on average, that was not the case for patents assigned to firms with R\&D labs. Although large firms’ patents (and those in the Middle Atlantic) were more likely to be in high-tech industries than those of small firms (and firms in the East North Central), the latter maintained a significant presence in these industries, especially according to our first, broader definition. Moreover, the direction of the relationship between large firms' investments in industrial research labs and the generation of hightech inventions is by no means certain. Large firms disproportionately acquired hightech patents in 1910-11, when only a few of them had research labs; many of the patents acquired by large firms with R\&D labs came from inventors located in a different state from the companies' labs; and there was no significant association between large-firm $\mathrm{R} \& \mathrm{D}$ and collaborative invention. Rather than enabling large firms to dominate the process of technological discovery, it may simply be, as Mowery and others have argued, that in-house research labs helped them make better decisions about which of the complicated second-industrial-revolution technologies being proffered on the market they should buy.

\section{The Role of Equity Markets}

For entrepreneurial firms to make important contributions to technological discovery, especially in the complex science-based technologies of the second industrial revolution, they needed to be able to raise capital. One clear advantage that large firms with $R \& D$ labs had over their entrepreneurial counterparts was ready access to the 
nation's main financial markets. As Table 9, Panel B shows, the vast majority of patents assigned to large firms (69.9 percent) and to firms with $R \& D$ labs (60.1 percent) went to enterprises whose shares were listed on the New York Stock Exchange (NYSE). By contrast, the proportion of patents acquired by entrepreneurial firms that were listed on the NYSE was comparatively miniscule (7.2 percent), and even if one adds to that firms whose equities traded on the secondary or regional exchanges, the total was still only 19.5 percent. Nonetheless, it is still possible that the growth of equity markets during the 1920s facilitated the formation of entrepreneurial startups. The promise of being able to go to the capital markets down the road may well have encouraged local financiers to invest in firms formed to exploit new technological discoveries.

If such a promise did help entrepreneurial startups obtain financing, the equity markets that mattered most would have been the regional exchanges and secondary New York markets like the Curb or the Produce Exchange—not the NYSE. Few entrepreneurial firms would have been able to jump directly to the Big Board because the requirements for listing were too stringent. Firms had to submit five years of financial statements as well as documents detailing their assets and liabilities, and relatively few passed the listing committee's muster. In 1927 the committee accepted 116 of 300 applications, in 192816 out of 571, and in 192980 out of 759 (White 2009). As a general rule, the only new firms that could meet the NYSE's standards were combinations formed by merger or firms with extensive financial backing that were born large in order to operate efficiently in industries characterized by economies of scale. Entrepreneurial startups would have had a much easier time listing on a regional exchange or a secondary market in New York because these exchanges deliberately 
adopted laxer standards in order to attract this kind of business (White 2009; Ripley 1927). Moreover, unlike the NYSE, listing was not a requirement for trading on these other exchanges. Whether there was a market for a firm's securities depended less on such formalities than on whether investors had sufficient information to evaluate the enterprise’s prospects. Reports in national financial publications like Moody's helped, but the kind of local knowledge that business people could accumulate about firms in their immediate vicinities probably mattered more.

It is difficult to get directly at the role that regional and secondary exchanges played in encouraging entrepreneurial enterprises because the equities of most such firms in our sample did not trade on any of the markets, at least not at the time we observe them (Tables 9 and 10). Indeed, most were too small even to be noticed by a publication such as Moody's. We can, however, get a sense of the importance of the different exchanges by focusing our attention on the smaller firms for which we do have financial reports. In 1928-29 enterprises with assets of less than \$10 million look much more like companies not covered by Moody’s than they do firms with more than $\$ 10$ million in assets. Whereas most of the assignments to firms in the larger asset category went to enterprises with R\&D labs, most of the assignments to these "small cap” firms went to companies that did not show up in the NRC lists as having industrial research facilities (Table 1). The proportion of their patents classified as high-tech was also more like that of companies in the “other” category than large-cap firms: for high-tech1, 56 percent for small-cap firms and 52 percent for other companies, compared to 74 percent for large-cap firms; and for high-tech2, 25 and 21, compared to 40 percent (Table 2, Panels C and D, 
and Table 1). ${ }^{19}$ The small-cap firms also look very different from the larger firms in that a much greater share of the patents they acquired came from inventors who were principals in the enterprise. In 1928-29 inventor principals generated 28 percent of the patents acquired by small-cap firms, compared to 26 percent for other companies and only 6 percent for large-cap firms (Table 2, Panel A, and Table 1). Finally, small-cap firms, like firms with inventor-principals more generally, were disproportionately located in the East North Central region of the country, whereas large firms were concentrated in the Middle Atlantic (Table 4).

For each of the small-cap and large-cap firms covered by Moody's, we collected information on the markets where the firm's equities traded (Table 10). Not surprisingly, unlike the case for large-cap firms, very few of the patents assigned to small-cap firms (only 6.1 percent) went to companies listed on the Big Board (Table 9, Panel B). However, over half went to a firm whose equities traded on at least one other exchange18.9 percent to firms that traded on a regional exchange, 15.5 percent to firms that traded on a secondary New York market, and 8.8 percent to firms that traded on both a regional exchange and a secondary New York market. The rest went to firms for which Moody's did not provide listing information, and it is likely that the stock of these companies was closely held or that it traded only privately. If we go further and break the data down regionally, we see that the securities of small-cap firms in the East North Central states were more likely to trade on regional equity markets, whereas those of small-cap firms in

\footnotetext{
19 The comparisons in this paragraph of all small-cap and all large-cap firms can be calculated using the counts in Table 1 as weights to add up the subcategories in Table 2. For the firms not included in Moody's, our figures on the proportion of inventors who were principals in the firms receiving their assignments are probably underestimates because we obtained this information by looking up the firms in city directories and thus were not able to check assignments to firms located in areas not covered by this source.
} 
New England and the Middle Atlantic were more likely to trade on a secondary New York market. ${ }^{20}$

When we trace the listing histories of the firms in our sample in earlier financial publications (Table 11), we find that that relatively few of them jumped from regional or secondary markets to the Big Board. The large-cap firms whose equities traded on the NYSE in 1929 were not just small-cap firms that grew big and shifted their listing. These firms for the most part were born large (often as a result of mergers), and their listing history seems to have begun on the NYSE. Similarly, most of the firms whose stock traded on regional exchanges in 1929 were first listed there, and the same was true for firms that traded on the secondary New York markets. The main exceptions were firms whose equities traded both on the secondary New York markets and on regional exchanges in 1929. A significant proportion of those firms started on a regional exchange and only later gained access to New York capital through a secondary market. Some firms, it seems, were able to market their equities on a local exchange and then, as investors accumulated more information about the firm's business, tap into broader markets in other regions. But most firms' access to capital markets remained local, with small firms in the East North Central turning primarily to exchanges in that region and those in the Middle Atlantic to secondary markets in New York.

Although the evidence is by no means conclusive, the information on listing locations is consistent with the idea that the growth of regional capital markets, especially in the East North Central states, encouraged investment in entrepreneurial startups. The most successful of these firms could anticipate being able to market their securities on exchanges in their home cities and perhaps move from there to one of the secondary

\footnotetext{
${ }^{20}$ We do not show these further breakdowns to save space and because of small cell sizes.
} 
markets in New York, and it may well be that this anticipation was enough to spur business people in such areas to risk some of their assets in new enterprises. Certainly, studies of Cleveland and Detroit by Lamoreaux, Levenstein, and Sokoloff (2006 and 2007) and Steven Klepper (2007) respectively point to the existence of local networks of notables eager to supply venture capital to innovative startups.

\section{The Reorganization of Inventive Activity}

We began this paper by discussing two literatures that have very different implications for our understanding of how the process of technological discovery was reorganized in the U.S. in the early twentieth century. On the one hand, the literature on the rise of industrial research labs claims that invention was increasingly moving into large firms' R\&D facilities. On the other, the literature on the growth of equity markets suggests that broadened access to funding enabled entrepreneurial firms to raise the capital they needed to play an ongoing role in technological discovery.

Our analysis of the patent data indicates that there is some truth to both of these perspectives. In the Middle Atlantic region of the country inventive activity was indeed moving into large firms' industrial research facilities. The East North Central, however, was home to a dynamic economy of entrepreneurial startups, supported (there is good reason to believe) by booming regional exchanges. Neither of these centers of inventive activity seems to have had a particular edge over the other during the 1920s, as the two regions accounted for roughly equivalent shares of total patents and had similar rates of patenting per capita. It is true that large firms in the Middle Atlantic were somewhat more specialized in the technologies associated with the second industrial revolution, but 
they had already developed this characteristic before they built most of their industrial research labs. Moreover, the inventions acquired by large firms with R\&D facilities were no more likely than those of firms without labs to be the product of teamwork, as measured by the presence of more than one name on the patent, and large firms still acquired a significant proportion of their patents from inventors whose state of residence indicates that they were unlikely to be employees of their assignees’ labs.

Why then has the literature on the history of technology focused on the large firms of the Middle Atlantic region and ignored the vibrant entrepreneurial economy further west? The answer, we think, lies in the events of the Great Depression, which hit small firms in the East North Central region much harder than large firms in the Middle Atlantic. $^{21}$ To measure the differential impact of the financial catastrophe on the two regions, we looked up the companies covered by Moody's in 1929 in the edition of the manual published in 1935 . We then estimated the probability that firms that obtained patents in 1929 would suffer financial distress by 1935. In the first four columns of Table 12, the dependent variable is a dummy that takes a value of one if the patent was assigned to a firm for which Moody's no longer published a report in 1935 or if the report indicated that the firm was in bankruptcy or being reorganized. ${ }^{22}$ In the second four columns, the dependent variable also includes firms whose access to capital markets seems to have deteriorated over the period 1929 to $1935 .^{23}$ All of the estimates are probits, and the independent variables have the same definitions as in the previous tables.

\footnotetext{
${ }^{21}$ On this point, see also Lamoreaux and Levenstein 2008.

${ }^{22}$ Most of the firms for which there were no reports were listed explicitly as dropped. If small firms ran into financial trouble, Moody's was likely to stop publishing information about them, but the journal usually continued to cover large firms in the same condition because the prospects of these enterprises were of interest to significant numbers of readers.

${ }^{23}$ For the precise definition of this variable, see the notes to Table 12.
} 
The differential impact of the depression is clear from the estimations. Although entrepreneurial firms do not seem to have been more negatively affected by the crisis than firms without patentee-principals, large firms were significantly less likely to suffer financial distress than small firms. ${ }^{24}$ Moreover, firms with their own R\&D facilities also came through the depression comparatively well. As we have seen, both large firms and firms with R\&D facilities were disproportionately located in the Middle Atlantic region. Yet even when we control for these characteristics, it is apparent that the depression hit that region less severely than it did other parts of the country. Of particular interest, of course, are the coefficients for the East North Central region. The point estimates are all suggestive of financial distress. They are significant at the 5 percent level in the second set of estimations and at the 10 percent level in the first. ${ }^{25}$

The effect of the depression is also apparent in regional patenting rates ( Figure 1), which held up much better during the 1930s in the Middle Atlantic than in the East North Central region. ${ }^{26}$ Given the low levels of demand during the Great Depression, large firms did not find building new productive capacity an attractive strategy. As Mowery and Nathan Rosenberg (1989) have shown, however, they greatly expanded their investments in $\mathrm{R} \& \mathrm{D} .{ }^{27}$ The number of new industrial research laboratories grew by 590 between 1929 and 1936, an increase that compares favorably with the 660 new labs founded between 1919 and 1928. Moreover, employment in industrial research labs shot up even more rapidly, multiplying nearly five times between 1927 and 1940 and raising

\footnotetext{
${ }^{24}$ This result, of course, is not at all surprising. On large firms' high survival rates from the 1920s to the 1960s, see Edwards 1975. More generally, see also Averitt 1968.

${ }^{25}$ We do not report estimations that control for technology subclasses because of small cell sizes, but the results are the same except that the coefficient on the East North Central dummy increases in significance.

${ }^{26}$ Patenting rates in any given year reflect applications made several years before. Hence the rise in patenting rates in most regions during the early years of the depression was a consequence of inventions generated mainly in the late 1920s.

${ }^{27}$ On this point, see also Bernstein 1987.
} 
the number of research employees per 1000 wage earners in firms with R\&D facilities from 0.83 to 3.67. As a result of these investments, large firms in the Middle Atlantic emerged from the depression with a stockpile of new technologies that enhanced their competitive position, whereas the smaller firms that survived in the East North Central had not been able to maintain the same level of patenting activity.

During World War II government procurement policy favored large firms with industrial research labs, further encouraging this trend (in all regions of the country), and the number of research employees in industry again doubled (Blum 1976, Vatter 1985, Mowery and Rosenberg 1989). When the economy revived in the war's aftermath, therefore, large firms in the East North Central looked a lot more like their counterparts in the Middle Atlantic. Moreover, the regional exchanges that had fostered local investment in entrepreneurial startups during the 1920s never recovered. The new Securities and Exchange Commission imposed general listing requirements equivalent to those on the NYSE on the regional and secondary exchanges, preventing those markets from continuing to provide a trading venue for enterprises that could not meet the Big Board's stringent standards (White 2009).

As a result of all these changes, little remained by the 1950s of the alternative entrepreneurial economy that had flourished during the 1920s in the East North Central part of the country. Its contributions to technological discovery have been largely erased from our historical memory, and the scholarship of the late twentieth century has been written as if innovative regions like Silicon Valley were something entirely new. Now that financial crises are once again buffeting the economy, it is useful to revisit this forgotten history. The differential impact of the Great Depression on the large-firm 
economy of the Middle Atlantic and the entrepreneurial economy of the East North Central is a stark reminder of the competitive advantages that large firms can reap under such circumstances as a consequence of their superior access to capital. It is also a useful warning about the dire consequences that macroeconomic shocks can have for innovative regions. 


\section{References}

Adams, Charles F., Jr. 1869. “A Chapter of Erie.” North American Review 109 (July): $30-106$

Adams, Stephen B., and Orville R. Butler. 1999. Manufacturing the Future: A History of Western Electric. New York: Cambridge University Press.

Arora, Ashish, Marco Ceccagnoli, and Wesley M. Cohen. 2007. "Trading Knowledge: An Exploration of Patent Protection and Other Determinants of Market Transactions in Technology and R\&D.” In Financing Innovation in the United States, 1870 to the Present, eds. Naomi R. Lamoreaux and Kenneth L. Sokoloff, 365-403. Cambridge, Mass.: MIT Press.

Arora, Ashish, Andrea Fosfuri, and Alfonso Gambardella. 2001. Markets for Technology: The Economics of Innovation and Corporate Strategy. Cambridge, Mass.: MIT Press.

Arrow, Kenneth J. 1962. "Economic Welfare and the Allocation of Resources for Invention.” In The Rate and Direction of Economic Activity: Economic and Social Factors, Universities-National Bureau Committee for Economic Research, 609-26. Princeton: Princeton University Press.

Averitt, Robert T. 1968. The Dual Economy: The Dynamics of American Industry Structure. New York: W. W. Norton.

Baskin, Jonathan Barron, and Paul J. Miranti, Jr. 1997. A History of Corporate Finance. New York: Cambridge University Press. 
Bernstein, Michael A. 1987. The Great Depression: Delayed Recovery and Economic Change in America, 1929-1939. New York: Cambridge University Press.

Blum, John Morton. 1976. V Was for Victory: Politics and Culture during World War II (San Diego, Cal.: Harcourt Brace Jovanovich.

Bulletin of the National Research Council. 1921. Pt. 1, No. 16 (December).

Bulleting of the National Research Council. 1927. No. 60 (July).

Bulletin of the National Research Council. 1946. No. 113 (July).

Calomiris, Charles W. 1995. "The Costs of Rejecting University Banking: American Finance in the German Mirror, 1870-1914.” In Coordination and Information: Historical Perspectives on the Organization of Enterprise, eds. Naomi R.

Lamoreaux and Daniel M. G. Raff, 257-315. Chicago: University of Chicago Press.

Carosso, Vincent P. 1970. Investment Banking in America: A History. Cambridge, Mass.: Harvard University Press.

Carosso, Vincent P. 1987. The Morgans: Private International Bankers, 1854-1913. Cambridge, Mass.: Harvard University Press.

Chandler, Alfred D., Jr. 1977. The Visible Hand: The Managerial Revolution in American Business. Cambridge, Mass.: Harvard University Press.

Cohen, Wesley M., and Steven Klepper. 1996. “A Reprise of Size and R\&D.” Economic Journal 106 (July): 925-51.

Cohen, Wesley M., Richard C. Levin, and David C. Mowery. 1987. "Firm Size and R\&D Intensity: A Re-examination.” Journal of Industrial Economics 35 (June): $543-65$. 
Cohen, Wesley M., Richard Nelson, and John P. Walsh. 2000. "Protecting their Intellectual Assets: Appropriability Condititions and Why U.S. Manufacturing Firms Patent (or Not).” NBER Working Paper 7552.

Commercial and Financial Chronicle. 1870-72 and 1890-91. New York: William P. Dana \& Co.

Cull, Robert, Lance E. Davis, Naomi R. Lamoreaux, and Jean-Laurent Rosenthal. 2006. "Historical Financing of Small- and Medium-Size Enterprises.” Journal of Banking and Finance 30 (November): 3017-42.

De Long, J. Bradford. 1991. “Did J. P. Morgan’s Men Add Value? An Economist’s Perspective on Financial Capitalism.” In Inside the Business Enterprise: Historical Perspectives on the Use of Information, ed. Peter Temin, 205-36. Chicago: University of Chicago Press.

Edwards, Richard C. 1975. "Stages in Corporate Stability and the Risks of Corporate Failure.” Journal of Economic History 35 (June): 428-57.

Federer, J. Peter. 2008. “Advances in Communication Technology and Growth of the American Over-the-Counter Markets, 1876-1929.” Journal of Economic History 68 (June): 501-34.

Fisk, Catherine L. 1998. "Removing the 'Fuel of Interest' from the 'Fire of Genius': Law and the Employee-Inventor, 1830-1930.” University of Chicago Law Review 65 (Fall): 1127-98.

Fisk, Catherine L. 2001. “Working Knowledge: Trade Secrets, Restrictive Covenants in Employment, and the Rise of Corporate Intellectual Property, 1800-1920.” Hastings Law Journal 52 (January): 441-535. 
Gans, Joshua, and Scott Stern. 2003. “The Product Market and the Market for 'Ideas': Commercialization Strategies for Technology Entrepreneurs.” Research Policy 32 (February): 333-50.

Gibb, George Sweet, and Evelyn H. Knowlton. 1956. History of Standard Oil Company (New Jersey), Vol. 2, The Resurgent Years, 1911-1927. New York: Harper \& Brothers.

Hall, Brownwyn H. 2006. “2002 Updates to NBER Patent Data.” http://elsa.berkeley.edu/ bhhall/bhdata.html (accessed October 2008).

Hall, Brownwyn H., Adam B. Jaffe, and Manuel Trajtenberg. 2002. “The NBER PatentCitation Data File: Lessons, Insights and Methodological Tools.” In Patents, Citations, and Innovations: A Window on the Knowledge Economy, eds. Adam B. Jaffe and Manuel Trajtenberg, 403-459. Cambridge, Mass: MIT Press.

Hintz, Eric S. 2007. “Independent Researchers in an Era of Burgeoning Research \& Development.” Business and Economic History On-Line 5, http://www.hnet.org/ business/bhcweb/publications/BEHonline/2007/hintz.pdf.

Hounshell, David A., and John Kenley Smith, Jr. 1988. Science and Corporate Strategy: Du Pont R\&D, 1902-1980. New York: Cambridge University Press.

Hughes, Thomas Parke. 1989. American Genesis: A Century of Invention and Technological Enthusiasm, 1870-1970. New York: Viking.

Jewkes, John, David Sawers, and Richard Stillerman. 1958. The Sources of Invention. London: Macmillan. 
Klepper, Steven. 2007. "The Organizing and Financing of Innovative Companies in the Evolution of the U.S. Automobile Industry.” In Financing Innovation in the United States, eds. Lamoreaux and Sokoloff, 85-128.

Lamoreaux, Naomi R., and Margaret Levenstein. 2008. “The Decline of an Innovative Region: Cleveland, Ohio, in the Twentieth Century.” Unpublished paper.

Lamoreaux, Naomi R., Margaret Levenstein, and Kenneth L. Sokoloff. 2006.

"Mobilizing Venture Capital During the Second Industrial Revolution: Cleveland, Ohio, 1870-1920.” Capitalism and Society 1, http://www.bepress.com/cas/vol1/iss3/art5/.

Lamoreaux, Naomi R., Margaret Levenstein, and Kenneth L. Sokoloff. 2007.

"Financing Invention during the Second Industrial Revolution: Cleveland, Ohio, 1870-1920.” In Financing Innovation in the United States, eds. Lamoreaux and Sokoloff, 39-84.

Lamoreaux, Naomi R., and Kenneth L. Sokoloff. 1996. "Long-Term Change in the Organization of Inventive Activity.” Proceedings of the National Academy of Sciences of the United States of America 93 (12 November): 12686-92.

Lamoreaux, Naomi R., and Kenneth L. Sokoloff. 1999. "Inventors, Firms, and the Market for Technology in the Late Nineteenth and Early Twentieth Centuries." In Learning by Doing in Markets, Firms and Countries, eds. Naomi R. Lamoreaux, Daniel M. G. Raff, and Peter Temin, 19-57. Chicago: University of Chicago Press. 
Lamoreaux, Naomi R., and Kenneth L. Sokoloff. 2001. "Market Trade in Patents and the Rise of a Class of Specialized Inventors in the Nineteenth-Century United States.” American Economic Review, Papers and Proceedings 91 (May): 39-44.

Lamoreaux, Naomi R., and Kenneth L. Sokoloff. 2003. "Intermediaries in the U.S. Market for Technology, 1870-1920.” In Finance, Intermediaries, and Economic Development, eds. Stanley L. Engerman, Philip T. Hoffman, Jean-Laurent Rosenthal, and Kenneth L. Sokoloff, 209-46. New York: Cambridge University Press.

Lamoreaux, Naomi R., and Kenneth L. Sokoloff. 2007. “The Market for Technology and the Organization of Invention in U.S. History.” In Entrepreneurship, Innovation, and the Growth Mechanism of the Free-Enterprise Economies, eds. Eytan Sheshinski, Robert J. Strom, and William J. Baumol, 213-43. Princeton: Princeton University Press.

Lamoreaux, Naomi R., and Kenneth L. Sokoloff. 2009. “The Rise and Decline of the Independent Inventor: A Schumpeterian Story?” In The Challenge of Remaining Innovative: Insights from Twentieth Century American Business, eds. Sally H. Clarke, Naomi R. Lamoreaux, and Steven W. Usselman, 43-78. Stanford: Stanford University Press.

Lanjouw, Jean O., and Mark Schankerman. 2004. "Patent Quality and Research Productivity; Measuring Innovation with Multiple Indicators.” Economic Journal 114 (April): 441-65.

Lazonick, William. 1991. Business Organization and the Myth of the Market Economy. New York: Cambridge University Press, 1991. 
Lerner, Josh. 1994. “The Importance of Patent Scope: An Empirical Analysis.” Rand Journal of Economics 25 (Summer): 319-33.

Lerner, Josh. 1995. "Patenting in the Shadow of Competitors." Journal of Law and Economics 38 (October): 463-95.

Leslie, Stuart W. 1980. “Thomas Midgley and the Politics of Industrial Research.” Business History Review 54 (Winter): 480-503.

Lipartito, Kenneth. 2009. "Rethinking the Invention Factory: Bell Laboratories in Perspective.” In The Challenge of Remaining Innovative, eds. Clarke, Lamoreaux, and Usselman, 132-59.

Martin, Joseph G. 1898. A Century of Finance: Martin's History of the Boston Stock and Money Markets. Boston: privately printed.

Moody’s Manual of Investments and Security Rating Service. 1924, 1929, and 1935.

New York: Moody’s Investors Service.

Mowery, David C. 1983. "The Relationship between Intrafirm and Contractual Forms of Industrial Research in American Manufacturing, 1900-1940.” Explorations in Economic History 20 (October): 351-74.

Mowery, David C. 1995. “The Boundaries of the U.S. Firm in R\&D.” In Coordination and Information, eds. Lamoreaux and Raff, 147-76.

Mowery, David C., and Nathan Rosenberg. 1989. Technology and the Pursuit of Economic Growth. New York: Cambridge University Press.

Navin, Thomas R., and Marian V. Sears. 1955. “The Rise of a Market for Industrial Securities, 1887-1902.” Business History Review 29 (June): 105-38. 
Neal, Larry, and Lance E. Davis. 2007. "Why Did Finance Capitalism and the Second Industrial Revolution Arise in the 1890s?” In Financing Innovation in the United States, eds. Lamoreaux and Sokoloff, 129-61.

Nelson, Richard R.. 1959. “The Simple Economics of Basic Scientific Research.” Journal of Political Economy 67 (June): 297-306.

Nicholas, Tom. 2003. “Why Schumpeter Was Right: Innovation, Market Power, and Creative Destruction in 1920s America.” Journal of Economic History 63 (December): 1023-58.

Nicholas, Tom. 2007. “Stock Market Swings and the Value of Innovation, 1908-1929.” In Financing Innovation in the United States, eds. Lamoreaux and Sokoloff, 217245.

Nicholas, Tom. 2008. “Does Innovation Cause Stock Market Runups? Evidence from the Great Crash.” American Economic Review 98 (Sept. 2008): 1370-96.

Nicholas, Tom. 2009. "Spatial Diversity in Invention: Evidence from the Early R\&D Labs.” Journal of Economic Geography 9 (January): 1-31.

O’Sullivan, Mary A. 2007. “Funding New Industries: A Historical Perspective on the Financing Role of the U.S. Stock Market in the Twentieth Century.” In Financing Innovation in the United States, eds. Lamoreaux and Sokoloff, 163216.

Poor's Manual of Industrials. 1910 and 1912. New York: Poor’s Railroad Manual Co. Reich, Leonard S. 1977. "Research, Patents, and the Struggle to Control Radio: A Study of Big Business and the Uses of Industrial Research.” Business History Review 51 (Summer): 208-35. 
Reich, Leonard S. 1980. "Industrial Research and the Pursuit of Corporate Security: The Early Years of Bell Labs.” Business History Review 54 (Winter): 504-29.

Reich, Leonard S. 1985. The Making of American Industrial Research: Science and Business at GE and Bell, 1876-1926. New York: Cambridge University Press.

Ripley, William Z. 1927. Main Street and Wall Street. Boston: Little, Brown \& Co.

Robb, John F. 1922. Patent Essentials for the Executive, Engineer, Lawyer and Inventor. New York: Funk \& Wagnalls.

Robinson, William G. 1890. The Law of Patents for Useful Inventions. Boston: Little, Brown \& Company. 3 vols.

Rosenbloom, Richard S., and William J. Spencer. 1996. “Introduction: Technology’s Vanishing Wellspring.” In Engines of Innovation: U.S. Industrial Research at the End of an Era, eds. Rosenbloom and Spencer, 1-9. Boston: Harvard Business School Press.

Scherer, F. M. 1965. "Firm Size, Market Structure, Opportunity, and the Output of Patented Inventions.” American Economic Review 55 (December): 1097-1125.

Schumpeter, Joseph A. 1942. Capitalism, Socialism, and Democracy. New York: Harper.

Simon, Miguel Cantillo. 1998. "The Rise And Fall of Bank Control in the United States: 1890-1939.” American Economic Review 88 (December): 1077-93

Smith, John K., and David A. Hounshell. 1985. "Wallace H. Carothers and Fundamental Research at Du Pont.” Science 229 (Aug. 2): 436-42. 
Teece, David J. 1986. “Profiting from Technological Innovation: Implications for Integration, Collaboration, Licensing, and Public Policy.” Research Policy 15 (December): 285-305.

Teece, David J. 1988. “Technological Change and the Nature of the Firm.” In Technical Change and Economic Theory, eds. Giovanni Dosi, Christopher Freeman, Richard Nelson, Gerald Silverberg, and Luc Soete, 256-81. London: Pinter.

Teece, David J. 1993. “The Dynamics of Industrial Capitalism: Perspectives on Alfred Chandler’s Scale and Scope.” Journal of Economic Literature 31 (March): 199225.

U.S. Census Bureau. 2002. “Demographic Trends in the 20 ${ }^{\text {th }}$ Century.” Census 2000 Special Reports, Series CENSR-4. http://www.census.gov/prod/2002pubs/censr4.pdf.

U.S. Commissioner of Patents. 1870-71, 1890-91, 1900-25, 1946, 1955. Annual Report. Washington: Government Printing Office.

Usselman, Steven W. 2002. Regulating Railroad Innovation: Business, Technology, and Politics in America, 1840-1920. New York: Cambridge University Press.

Usselman, Steven W. 2007. “Learning the Hard Way: IBM and the Sources of Innovation in Early Computing," in Financing Innovation in the United States, eds. Lamoreaux and Sokoloff, 317-63.

Vatter, Harold G. 1985. The U.S. Economy in World War II. New York: Columbia University Press. 
White, Eugene N. 1984. “Banking Innovation in the 1920s: The Growth of National Banks’ Financial Services.” Business and Economic History, Second Series 13: 92-104.

White, Eugene N. 1990. “The Stock Market Boom and Crash of 1929 Revisited.” Journal of Economic Perspectives 4 (Spring): 67-83.

White, Eugene N. 2009. “Competition Among the Exchanges Before the SEC: Was the NYSE a Natural Hegemon?” Unpublished paper.

White, Richard. 2003. “Information, Markets, and Corruption: Transcontinental Railroads in the Gilded Age.” Journal of American History 90 (June): 19-43.

Wise, George. 1985. Willis R. Whitney, General Electric, and the Origins of U.S. Industrial Research. New York: Columbia University Press.

Zeckhauser, Richard. 1996. “The Challenge of Contracting for Technological Information.” Proceedings of the National Academy of Sciences of the United States of America 93 (12 November): 12743-48. 
Table 1: Distribution of Patents and Assignments at Issue by Type of Company

\begin{tabular}{|c|c|c|c|c|c|c|c|c|}
\hline \multirow[b]{3}{*}{$\begin{array}{c}\text { Sample } \\
\text { year }\end{array}$} & \multirow[b]{3}{*}{$\begin{array}{c}\text { Number of } \\
\text { obser- } \\
\text { vations }\end{array}$} & \multicolumn{7}{|c|}{ "Distribution (row percentages) } \\
\hline & & \multirow[b]{2}{*}{$\begin{array}{c}\% \text { not } \\
\text { assigned }\end{array}$} & \multicolumn{5}{|c|}{ Assigned to a company with a financial report } & \multirow[b]{2}{*}{$\begin{array}{c}\% \text { assigned } \\
\text { to other } \\
\text { company }\end{array}$} \\
\hline & & & $\begin{array}{c}\% \text { assigned } \\
\text { to } \\
\text { individual } \\
\end{array}$ & $\begin{array}{c}\text { Assets }>= \\
\% \text { with } \\
\text { R\&D lab }\end{array}$ & $\begin{array}{c}\$ 10 \text { million } \\
\text { \% with no } \\
\text { R\&D lab }\end{array}$ & $\begin{array}{c}\frac{\text { Assets }<}{\% \text { with }} \\
\text { R\&D lab }\end{array}$ & $\begin{array}{c}\$ 10 \text { million } \\
\% \text { with no } \\
\text { R\&D lab }\end{array}$ & \\
\hline \multicolumn{9}{|c|}{ Panel A: Percent of patents } \\
\hline $1870-71$ & 1,425 & 83.9 & 13.4 & 0.0 & 0.1 & 0.0 & 0.0 & 2.6 \\
\hline 1890-91 & 2,022 & 70.8 & 15.7 & 0.0 & 0.4 & 0.0 & 0.0 & 13.0 \\
\hline $1910-11$ & 2,498 & 69.2 & 11.0 & 1.2 & 2.2 & 0.2 & 2.6 & 13.5 \\
\hline 1928-29 & 2,297 & 43.9 & 7.2 & 16.1 & 4.4 & 2.0 & 4.4 & 22.1 \\
\hline \multicolumn{9}{|c|}{ Panel B: Percent of patents assigned to companies } \\
\hline 1870-71 & 38 & & & 0.0 & 2.6 & 0.0 & 0.0 & 97.4 \\
\hline $1890-91$ & 273 & & & 0.4 & 2.9 & 0.0 & 0.4 & 96.3 \\
\hline $1910-11$ & 494 & & & 6.3 & 11.3 & 0.8 & 13.2 & 68.4 \\
\hline $1928-29$ & 1,124 & & & 32.8 & 8.9 & 4.1 & 9.1 & 45.1 \\
\hline \multicolumn{9}{|c|}{ Panel C: Percent of companies that obtained assignments } \\
\hline $1870-71$ & 35 & & & 0.0 & 2.9 & 0.0 & 0.0 & 97.1 \\
\hline $1890-91$ & 220 & & & 0.5 & 1.4 & 0.0 & 0.5 & 97.7 \\
\hline $1910-11$ & 372 & & & 3.2 & 5.6 & 0.8 & 11.6 & 78.8 \\
\hline $1928-29$ & 787 & & & 14.5 & 8.9 & 5.0 & 11.3 & 60.4 \\
\hline
\end{tabular}

Sources and Notes: The observations in Panels A and B are random samples of patents taken from the Annual Reports of the Commissioner of Patents for the years 1870-71, 1890-91, 1910-11, and 1928-29. We report only utility patents awarded to residents of the United States, excluding patents assigned to foreign companies and patents that were reissued. "Not assigned" means that the patent was not sold or otherwise transferred by the time it was issued. We break assignments at issue into categories according to the identity of the assignee: first, whether the assignee was an individual or a company; and second, if it was a company, whether it was the subject of a report in a financial publication (the Commercial and Financial Chronicle for the 1870-71 and 1890-91 cross sections; Poor's Manual of Industrials for 1910-11; and Moody's Manual for 1928-29). We divided companies for which financial reports existed into two classes according to the amount of assets on their balance sheets. If no information on assets was reported for a firm, we used its total capitalization instead. If the firm was part of a larger company, wherever possible we used the data for the parent on the grounds that that information better reflected the financial resources available to the enterprise. Information on whether a company had a research lab came from the surveys published in the Bulletin of the National Research Council for 1921, 1927, and 1946. We considered the firm to have a research lab if it was listed as having one in a survey conducted before the year of the cross-sectional sample or if the 1946 survey, which included historical information, listed a founding date for the lab that was before the year of the cross section. A few firms in the category "other company" had industrial research labs, though to save space, we do not provide the breakdown in this table. The observations in Panel $\mathrm{C}$ are the companies 
to which the patents in the respective cross-sectional samples were assigned. In a few cases more than one of the assignee companies are subsidiaries of the same larger company. 
Table 2: Characteristics of Patents by Type of Assignee

\begin{tabular}{|c|c|c|c|c|c|c|c|c|}
\hline \multirow[b]{3}{*}{$\begin{array}{c}\text { Sample } \\
\text { year }\end{array}$} & \multirow[b]{3}{*}{$\begin{array}{c}\text { All } \\
\text { patents }\end{array}$} & \multirow[b]{3}{*}{$\begin{array}{c}\text { Not } \\
\text { assigned }\end{array}$} & \multicolumn{6}{|c|}{ Assigned to company with a financial report } \\
\hline & & & \multirow[b]{2}{*}{$\begin{array}{l}\text { Assigned } \\
\text { to } \\
\text { individual }\end{array}$} & \multicolumn{2}{|c|}{ Assets $>=\$ 10$} & \multicolumn{2}{|c|}{ Assets $<\$ 10$ million } & \multirow[b]{2}{*}{$\begin{array}{c}\text { Assigned } \\
\text { to other } \\
\text { company }\end{array}$} \\
\hline & & & & $\begin{array}{c}\text { Had } \\
\text { R\&D } \\
\text { lab }\end{array}$ & $\begin{array}{l}\text { No } \\
\text { R\&D } \\
\text { lab }\end{array}$ & $\begin{array}{c}\text { Had } \\
\text { R\&D } \\
\text { Lab }\end{array}$ & $\begin{array}{l}\text { No } \\
\text { R\&D } \\
\text { lab }\end{array}$ & \\
\hline \multicolumn{9}{|c|}{ Panel A: Proportion where the patentee was a principal of the company } \\
\hline 1910-11 & 0.04 & n.a. & n.a. & 0.06 & 0.02 & 0.50 & 0.22 & 0.26 \\
\hline 1928-29 & 0.09 & n.a. & п.а. & 0.04 & 0.11 & 0.20 & 0.31 & 0.26 \\
\hline \multicolumn{9}{|c|}{ Panel B: Proportion cited by a patent obtained in 1975-2002 } \\
\hline $1910-11$ & 0.23 & 0.25 & 0.18 & 0.03 & 0.18 & 0.25 & 0.11 & 0.18 \\
\hline 1928-29 & 0.33 & 0.36 & 0.35 & 0.25 & 0.31 & 0.30 & 0.30 & 0.32 \\
\hline \multicolumn{9}{|c|}{ Panel C: Proportion high-tech1 } \\
\hline $1910-11$ & 0.32 & 0.29 & 0.36 & 0.39 & 0.77 & 0.25 & 0.38 & 0.34 \\
\hline 1928-29 & 0.50 & 0.37 & 0.58 & 0.78 & 0.53 & 0.57 & 0.55 & 0.52 \\
\hline \multicolumn{9}{|c|}{ Panel D: Proportion high-tech2 } \\
\hline $1910-11$ & 0.15 & 0.13 & 0.17 & 0.19 & 0.52 & 0.00 & 0.14 & 0.19 \\
\hline 1928-29 & 0.24 & 0.18 & 0.24 & 0.46 & 0.15 & 0.37 & 0.20 & 0.21 \\
\hline \multicolumn{9}{|c|}{ Panel E: Proportion collaborative } \\
\hline 1910-11 & 0.08 & 0.08 & 0.07 & 0.10 & 0.11 & 0.50 & 0.06 & 0.08 \\
\hline $1928-29$ & 0.10 & 0.07 & 0.14 & 0.14 & 0.10 & 0.11 & 0.12 & 0.10 \\
\hline
\end{tabular}

Sources and Notes: For a description of the cross-sectional samples of patents and the categories of assignees, see Table 1 . We considered the patentee to be a principal if the company obtaining the assignment bore the surname of the inventor or if information in a financial publication or city directory revealed that the patentee was an officer, director, or proprietor of the company. Data on citations from 1975-2002 come from Bronwyn H. Hall, “2002 Updates to NBER Patent Data,” http://elsa.berkeley.edu/ bhhall/bhdata.html, last updated 5 Sept 2006. See Hall, Jaffe, and Trajtenberg (2002) for further information. We classified patents in the 1910-11 and 1928-29 samples by technology in two different ways. For high-tech1, we categorized a patent as high tech if, based on our reading of the patent, it pertained to electrical machinery and products, chemicals, petroleum, plastics and rubber, automobiles, primary metals, mining machinery, and transportation equipment, as well as the machinery used in production in these industries. For hightech2, we defined as high-tech patents that were classified by Hall et al. (2002) as falling in technology subclasses 11-49 (based on the U.S. Patent and Trademark Office's classification scheme). These subclasses include patents in chemicals, computers and communication technology, drugs and medical devices, and electrical and electronics. We consider a patent to have been collaborative if it the number of patentees on the grant was greater than one. 
Table 3: Distribution of Patents and Patent Claims by Type of Assignee (Row Percentages)

\begin{tabular}{|c|c|c|c|c|c|c|c|}
\hline \multirow[b]{3}{*}{$\begin{array}{c}\text { Sample } \\
\text { year }\end{array}$} & \multirow[b]{3}{*}{$\begin{array}{c}\text { Not } \\
\text { assigned }\end{array}$} & \multirow[b]{3}{*}{$\begin{array}{l}\text { Assigned } \\
\text { to } \\
\text { individual }\end{array}$} & \multicolumn{4}{|c|}{ Assigned to company with a financial report } & \multirow[b]{3}{*}{$\begin{array}{l}\text { Assigned } \\
\text { to other } \\
\text { company }\end{array}$} \\
\hline & & & Asse & $=\$ 10$ & Assets & 0 millio & \\
\hline & & & $\begin{array}{c}\text { Had } \\
\text { R\&D } \\
\text { lab }\end{array}$ & $\begin{array}{c}\text { No } \\
\text { R\&D } \\
\text { lab }\end{array}$ & $\begin{array}{c}\text { Had } \\
\text { R\&D } \\
\text { lab }\end{array}$ & $\begin{array}{c}\text { No } \\
\text { R\&D } \\
\text { lab }\end{array}$ & \\
\hline
\end{tabular}

Panel A: Distribution of patents where the patentee was a principal of the company

$\begin{array}{llllllll}1910-11 & \text { n.a. } & \text { n.a. } & 1.9 & 0.9 & 1.9 & 13.2 & 82.1 \\ 1928-29 & \text { n.a. } & \text { n.a. } & 7.1 & 5.6 & 4.6 & 16.3 & 66.3\end{array}$

Panel B: Distribution of patents cited by a patent obtained in 1975-2002

$\begin{array}{cccccccc}1910-11 & 76.9 & 8.9 & 0.2 & 1.8 & 0.2 & 1.2 & 10.8 \\ 1928-29 & 48.3 & 7.7 & 12.2 & 4.1 & 1.9 & 4.0 & 21.8\end{array}$

Panel C: Distribution of patents classified as high-tech1

$\begin{array}{cccccccc}1910-11 & 62.9 & 12.4 & 1.5 & 5.4 & 0.1 & 3.2 & 14.4 \\ 1928-29 & 32.4 & 8.3 & 24.8 & 4.6 & 2.3 & 4.9 & 22.7\end{array}$

Panel D: Distribution of patents classified as high-tech 2

\begin{tabular}{|c|c|c|c|c|c|c|c|}
\hline $1910-11$ & 60.2 & 11.9 & 1.6 & 7.5 & 0.0 & 2.3 & 16.5 \\
\hline $1928-29$ & 33.5 & 7.1 & 30.7 & 2.7 & 3.1 & 3.6 & 19.3 \\
\hline \multicolumn{8}{|c|}{ Panel E: Distribution of patent claims } \\
\hline 1910-11 & 59.1 & 11.7 & 3.6 & 4.6 & 0.2 & 3.2 & 17.6 \\
\hline $1928-29$ & 34.7 & 7.4 & 19.5 & 7.1 & 2.3 & 5.2 & 23.8 \\
\hline
\end{tabular}

Notes and Sources: See Tables 1 and 2. We do not report the distribution for collaborative patents because the number of patents that named more than one inventor was so small. Patent claims are the number of individual claims for novel technological contributions that the Patent Office approved in the text of the patent. 
Table 4: Regional Shares of Patents by Assignee Type (Column Percentages)

\begin{tabular}{|c|c|c|c|c|c|c|c|c|c|c|c|c|}
\hline \multirow[b]{3}{*}{ Region } & \multirow[b]{3}{*}{$\begin{array}{c}\text { All } \\
\text { patents }\end{array}$} & \multirow[b]{3}{*}{$\begin{array}{c}\text { Not } \\
\text { Assigned } \\
\end{array}$} & \multicolumn{4}{|c|}{ For each type of assignment } & \multirow{3}{*}{\multicolumn{2}{|c|}{$\begin{array}{|cc|} & \text { Com- } \\
& \text { pany } \\
& \text { assign- } \\
\text { Com- } & \text { ment with } \\
\text { pany } & \text { missing } \\
\text { assign- } & \text { inform- } \\
\text { ment by } & \text { ation on } \\
\text { prin-cipal } & \text { prin-cipal } \\
\end{array}$}} & \multirow{3}{*}{$\begin{array}{c}\text { Patent } \\
\text { cited } \\
\text { during } \\
1975- \\
2002 \\
\end{array}$} & \multirow{3}{*}{$\begin{array}{l}\text { Patent } \\
\text { is } \\
\text { high- } \\
\text { tech1 }\end{array}$} & \multirow{3}{*}{$\begin{array}{c}\text { Patent } \\
\text { is } \\
\text { high- } \\
\text { tech2 }\end{array}$} & \multirow{3}{*}{$\begin{array}{c}\text { Total } \\
\text { numbe } \\
\text { of } \\
\text { claims }\end{array}$} \\
\hline & & & \multirow[b]{2}{*}{$\begin{array}{c}\text { Assigned } \\
\text { to Indi- } \\
\text { vidual } \\
\end{array}$} & \multicolumn{2}{|c|}{$\begin{array}{c}\text { Assigned to } \\
\text { company with a } \\
\text { financial report }\end{array}$} & \multirow[b]{2}{*}{$\begin{array}{c}\text { Assigned } \\
\text { to other } \\
\text { company } \\
\end{array}$} & & & & & & \\
\hline & & & & $\begin{array}{l}\text { Assets } \\
>=\$ 10 \\
\text { million } \\
\end{array}$ & $\begin{array}{l}\text { Assets } \\
<\$ 10 \\
\text { million } \\
\end{array}$ & & & & & & & \\
\hline \multicolumn{13}{|l|}{ Panel A: 1910-11 } \\
\hline West & 10.6 & 12.3 & 11.6 & 1.1 & 0.0 & 5.9 & 8.5 & 4.8 & 12.3 & 10.5 & 9.0 & 8.9 \\
\hline West North Central & 11.2 & 13.6 & 8.7 & 4.6 & 5.8 & 4.1 & 5.7 & 4.8 & 9.4 & 11.0 & 8.3 & 9.1 \\
\hline East North Central & 26.1 & 25.9 & 23.9 & 14.9 & 23.2 & 32.5 & 40.6 & 15.6 & 27.9 & 27.1 & 23.5 & 26.4 \\
\hline New England & 9.7 & 7.6 & 11.2 & 2.3 & 33.3 & 16.3 & 19.8 & 19.9 & 9.1 & 8.0 & 11.9 & 11.1 \\
\hline Middle Atlantic & 29.8 & 26.2 & 28.3 & 75.9 & 36.2 & 36.1 & 18.9 & 51.6 & 29.5 & 32.8 & 37.7 & 34.8 \\
\hline South Atlantic & 2.1 & 2.0 & 4.0 & 1.1 & 0.0 & 2.1 & 0.9 & 2.2 & 2.1 & 2.5 & 1.8 & 2.1 \\
\hline Other South & 10.4 & 12.4 & 12.3 & 0.0 & 1.4 & 3.0 & 5.7 & 1.1 & 9.8 & 8.1 & 7.8 & 7.7 \\
\hline \multicolumn{13}{|l|}{ Panel B: 1928-29 } \\
\hline West & 10.4 & 16.4 & 15.8 & 1.7 & 2.7 & 6.9 & 5.1 & 8.2 & 11.6 & 7.5 & 10.0 & 8.1 \\
\hline West North Central & 6.9 & 9.6 & 12.1 & 1.9 & 4.1 & 5.3 & 6.1 & 3.1 & 7.4 & 6.3 & 3.8 & 5.4 \\
\hline East North Central & 30.1 & 26.4 & 20.0 & 29.0 & 44.6 & 37.5 & 43.9 & 32.8 & 29.3 & 32.0 & 27.3 & 30.5 \\
\hline New England & 10.0 & 6.6 & 9.1 & 11.5 & 20.3 & 12.4 & 14.8 & 10.9 & 9.4 & 6.9 & 8.7 & 12.2 \\
\hline Middle Atlantic & 33.7 & 28.6 & 27.3 & 53.5 & 25.7 & 29.8 & 23.5 & 35.5 & 33.3 & 38.0 & 42.0 & 37.2 \\
\hline South Atlantic & 2.4 & 1.5 & 4.8 & 1.7 & 2.0 & 4.3 & 3.6 & 6.3 & 1.9 & 2.9 & 3.3 & 2.3 \\
\hline Other South & 6.6 & 10.9 & 10.9 & 0.6 & 0.7 & 3.7 & 3.1 & 3.1 & 7.0 & 6.3 & 4.9 & 4.3 \\
\hline
\end{tabular}


Notes and Sources: See Tables 1 and 2. Regions are the locations of the assignees. The West includes Arizona, California, Colorado, Idaho, Montana, Nevada, New Mexico, Oregon, Utah, Washington, and Wyoming; the West North Central Iowa, Kansas, Minnesota, Missouri, Nebraska, North Dakota, and South Dakota; the East North Central Illinois, Indiana, Michigan, Ohio, and Wisconsin; New England Connecticut, Maine, Massachusetts, New Hampshire, Rhode Island, and Vermont; the Middle Atlantic New Jersey, New York, and Pennsylvania; the South Atlantic Delaware, the District of Columbia, and Maryland; the Other South Alabama, Arkansas, Florida, Georgia, Kentucky, Louisiana, Mississippi, North Carolina, Oklahoma, South Carolina, Tennessee, Texas, Virginia, and West Virginia. 
Table 5: Distribution of Patents within Regions by Assignment Categories and by Patent Characteristics

\begin{tabular}{|c|c|c|c|c|c|c|c|c|c|c|c|c|c|}
\hline \multirow[b]{4}{*}{ Region } & \multirow[b]{4}{*}{$\begin{array}{l}\text { No. of } \\
\text { patents }\end{array}$} & \multicolumn{10}{|c|}{ Row Percent of Patents } & \multirow{2}{*}{\multicolumn{2}{|c|}{$\begin{array}{l}\text { Row Percent of } \\
\text { Company } \\
\text { Assignments } \\
\end{array}$}} \\
\hline & & & \multirow{2}{*}{\multicolumn{6}{|c|}{$\begin{array}{c}\text { Assigned to a company with } \\
\text { a financial report } \\
\text { Assets }>=\$ 10 \text { million } \underline{\text { Assets }<\$ 10 \text { million }}\end{array}$}} & \multirow{3}{*}{$\begin{array}{l}\text { Cited } \\
\text { during } \\
1975- \\
2002 \\
\end{array}$} & \multirow{3}{*}{$\begin{array}{l}\text { That } \\
\text { are } \\
\text { high- } \\
\text { tech1 }\end{array}$} & \multirow{3}{*}{$\begin{array}{l}\text { That } \\
\text { are } \\
\text { high- } \\
\text { tech2 }\end{array}$} & & \\
\hline & & & & & & & & & & & & \multirow[b]{2}{*}{$\begin{array}{l}\text { Made by } \\
\text { principal }\end{array}$} & \multirow{2}{*}{$\begin{array}{l}\text { Missing } \\
\text { inform- } \\
\text { tion on } \\
\text { principal }\end{array}$} \\
\hline & & & $\begin{array}{l}\text { Assigned } \\
\text { to Indi- } \\
\text { vidual }\end{array}$ & $\begin{array}{c}\text { Had } \\
\mathrm{R} \& \mathrm{D} \\
\mathrm{lab}\end{array}$ & $\begin{array}{c}\text { No } \\
\text { R\&D } \\
\text { lab }\end{array}$ & $\begin{array}{c}\text { Had } \\
\text { R\&D } \\
\text { lab }\end{array}$ & $\begin{array}{c}\text { No } \\
\text { R\&D } \\
\text { lab }\end{array}$ & $\begin{array}{c}\text { Assigned } \\
\text { to other } \\
\text { company }\end{array}$ & & & & & \\
\hline \multicolumn{14}{|l|}{ Panel A: $1910-11$} \\
\hline West & 266 & 80.1 & 12.0 & 0.0 & 0.4 & 0.0 & 0.0 & 7.5 & 25.9 & 31.2 & 13.2 & 42.9 & 42.9 \\
\hline West North Central & 281 & 83.6 & 8.5 & 0.0 & 1.4 & 0.0 & 1.4 & 5.0 & 18.9 & 31.0 & 11.4 & 27.3 & 40.9 \\
\hline East North Central & 652 & 68.6 & 10.1 & 0.8 & 1.2 & 0.0 & 2.5 & 16.9 & 24.1 & 32.8 & 14.0 & 30.9 & 20.9 \\
\hline New England & 242 & 54.1 & 12.8 & 0.4 & 0.4 & 1.2 & 8.3 & 22.7 & 21.1 & 26.0 & 19.0 & 26.3 & 46.3 \\
\hline Middle Atlantic & 744 & 60.9 & 10.5 & 3.2 & 5.6 & 0.1 & 3.2 & 16.4 & 22.3 & 34.8 & 19.6 & 9.4 & 45.1 \\
\hline South Atlantic & 53 & 64.2 & 20.8 & 1.9 & 0.0 & 0.0 & 0.0 & 13.2 & 22.6 & 37.7 & 13.2 & 12.5 & 50.0 \\
\hline Other South & 260 & 82.7 & 13.1 & 0.0 & 0.0 & 0.0 & 0.4 & 3.8 & 21.2 & 24.6 & 11.5 & 54.5 & 18.2 \\
\hline \multicolumn{14}{|l|}{ Panel B: 1928-29 } \\
\hline West & 238 & 69.3 & 10.9 & 1.7 & 1.7 & 0.4 & 1.3 & 14.7 & 36.6 & 36.6 & 23.1 & 21.3 & 44.7 \\
\hline West North Central & 159 & 61.0 & 12.6 & 2.5 & 3.1 & 1.9 & 1.9 & 17.0 & 35.2 & 45.9 & 13.2 & 28.6 & 19.0 \\
\hline East North Central & 691 & 38.5 & 4.8 & 14.9 & 4.8 & 2.5 & 7.1 & 27.5 & 32.0 & 53.4 & 21.7 & 21.9 & 21.4 \\
\hline New England & 229 & 29.3 & 6.6 & 16.6 & 7.0 & 3.9 & 9.2 & 27.5 & 31.0 & 34.9 & 21.0 & 19.7 & 19.0 \\
\hline Middle Atlantic & 773 & 37.3 & 5.8 & 27.2 & 5.3 & 1.8 & 3.1 & 19.5 & 32.5 & 56.7 & 29.9 & 10.5 & 20.7 \\
\hline South Atlantic & 56 & 26.8 & 14.3 & 14.3 & 0.0 & 1.8 & 3.6 & 39.3 & 25.0 & 58.9 & 32.1 & 21.2 & 48.5 \\
\hline Other South & 151 & 72.8 & 11.9 & 1.3 & 0.7 & 0.7 & 0.0 & 12.6 & 35.1 & 48.3 & 17.9 & 26.1 & 34.8 \\
\hline
\end{tabular}

Notes and Sources: See Tables 1, 2, and 4. 
Table 6: Regional Distribution of Assignee Companies by Type

\begin{tabular}{|c|c|c|c|c|c|c|c|}
\hline \multirow[b]{3}{*}{ Region } & \multirow[b]{3}{*}{$\begin{array}{c}\text { No. of } \\
\text { firms }\end{array}$} & \multicolumn{3}{|c|}{ Column Percentages } & \multicolumn{3}{|c|}{ Row Percentages } \\
\hline & & \multicolumn{2}{|c|}{$\begin{array}{l}\text { Company had a } \\
\text { Financial Report }\end{array}$} & \multirow[b]{2}{*}{$\begin{array}{c}\text { Other } \\
\text { company }\end{array}$} & \multicolumn{2}{|c|}{$\begin{array}{l}\text { Company had a } \\
\text { Financial Report }\end{array}$} & \multirow[b]{2}{*}{$\begin{array}{c}\text { Other } \\
\text { company }\end{array}$} \\
\hline & & $\begin{array}{c}\text { Assets } \\
>=\$ 10 \\
\text { million }\end{array}$ & $\begin{array}{l}\text { Assets } \\
<\$ 10 \\
\text { million }\end{array}$ & & $\begin{array}{c}\text { Assets } \\
>=\$ 10 \\
\text { million }\end{array}$ & $\begin{array}{l}\text { Assets } \\
<\$ 10 \\
\text { million }\end{array}$ & \\
\hline \multicolumn{8}{|l|}{ Panel A: 1910-11 } \\
\hline West & 20 & 3.1 & 0.0 & 6.5 & 5.0 & 0.0 & 95.0 \\
\hline West North Central & 17 & 3.1 & 8.5 & 4.1 & 5.9 & 23.5 & 70.6 \\
\hline East North Central & 116 & 18.8 & 29.8 & 32.8 & 5.2 & 12.1 & 82.8 \\
\hline New England & 63 & 6.3 & 25.5 & 16.7 & 3.2 & 19.0 & 77.8 \\
\hline Middle Atlantic & 138 & 65.6 & 34.0 & 34.5 & 15.2 & 11.6 & 73.2 \\
\hline South Atlantic & 7 & 3.1 & 0.0 & 2.0 & 14.3 & 0.0 & 85.7 \\
\hline Other South & 11 & 0.0 & 2.1 & 3.4 & 0.0 & 9.1 & 90.9 \\
\hline \multicolumn{8}{|l|}{ Panel B: 1928-29 } \\
\hline West & 43 & 2.7 & 3.1 & 7.2 & 11.6 & 9.3 & 79.1 \\
\hline West North Central & 38 & 3.8 & 4.7 & 5.3 & 18.4 & 15.8 & 65.8 \\
\hline East North Central & 288 & 32.1 & 43.8 & 36.4 & 20.5 & 19.4 & 60.1 \\
\hline New England & 107 & 12.5 & 18.8 & 12.6 & 21.5 & 22.4 & 56.1 \\
\hline Middle Atlantic & 262 & 45.7 & 26.6 & 30.3 & 32.1 & 13.0 & 55.0 \\
\hline South Atlantic & 26 & 1.6 & 2.3 & 4.2 & 11.5 & 11.5 & 76.9 \\
\hline Other South & 23 & 1.6 & 0.8 & 4.0 & 13.0 & 4.3 & 82.6 \\
\hline
\end{tabular}

Notes and Sources: See Tables 1, 2, and 4. We assigned companies that had facilities in different states to a region on the basis of the location recorded on the earliest patent they received in the sample years. 
Table 7: Whose Patents were Important?

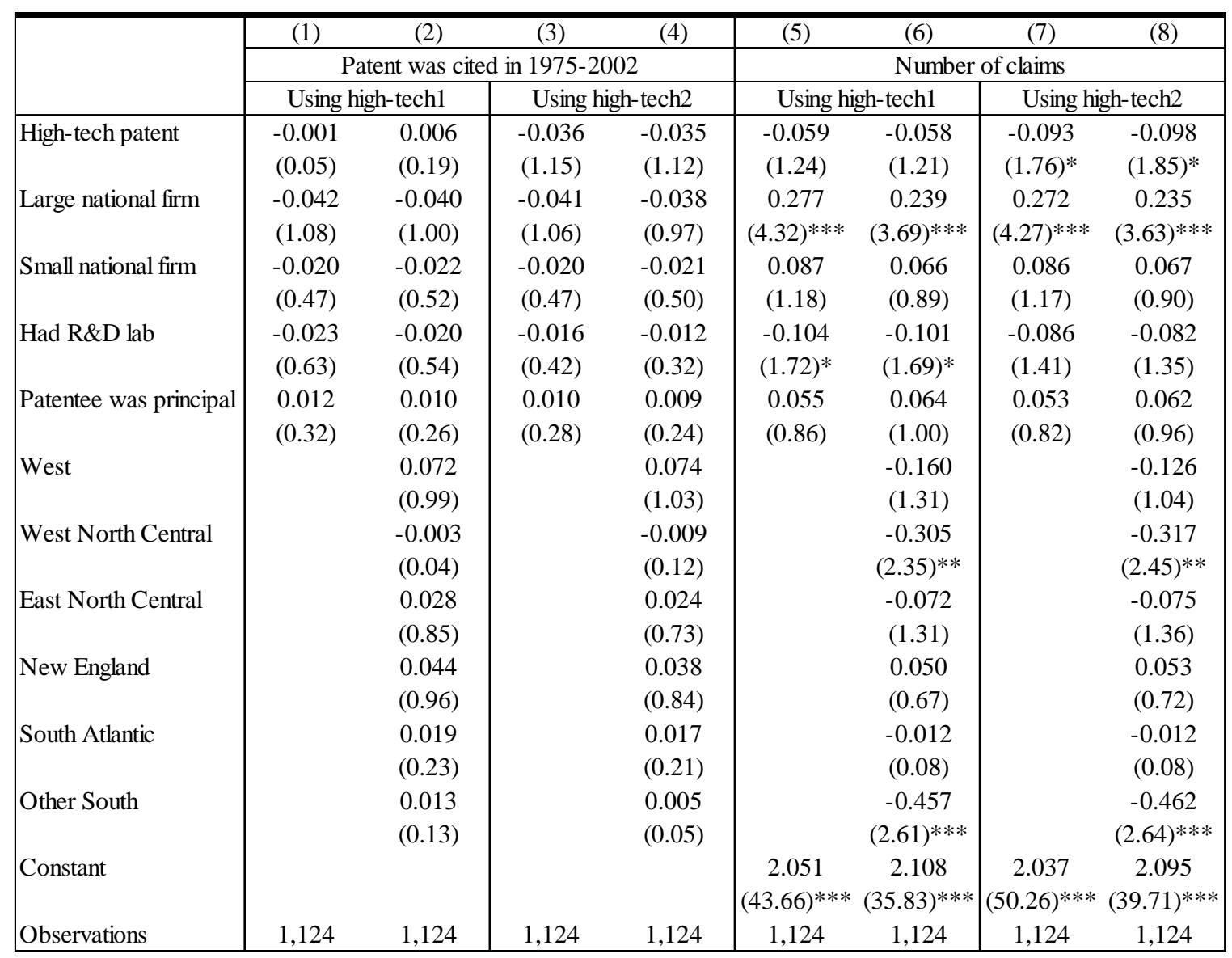

* significant at $10 \%$; ** significant at $5 \%$; *** significant at $1 \%$

Notes and Sources: The absolute value of $\mathrm{z}$ statistics are in parentheses. Columns 1 through 4 are probits, and the reported figures are the marginal effects. Columns 5 through 8 are negative binomial regressions. Observations are patents in the 1928-29 cross section that were assigned to companies. For definitions of the other variables, see Tables 1, 2, and 4. 
Table 8: Whose Patents Were High-Tech? Collaborative?

\begin{tabular}{|c|c|c|c|c|c|c|c|c|}
\hline & (1) & (2) & (3) & (4) & (5) & (6) & (7) & (8) \\
\hline & \multicolumn{4}{|c|}{ Patent was high-tech } & \multicolumn{4}{|c|}{ Patent was collaborative } \\
\hline & \multicolumn{2}{|c|}{ Using high-tech1 } & \multicolumn{2}{|c|}{ Using high-tech2 } & \multicolumn{2}{|c|}{ Using high-tech1 } & \multicolumn{2}{|c|}{ Using high-tech2 } \\
\hline High-tech patent & & & & & $\begin{array}{l}-0.005 \\
(0.22)\end{array}$ & $\begin{array}{l}-0.007 \\
(0.35)\end{array}$ & $\begin{array}{l}-0.023 \\
(1.09)\end{array}$ & $\begin{array}{c}-0.026 \\
(1.19)\end{array}$ \\
\hline Large national firm & $\begin{array}{c}0.113 \\
(2.72)^{* * *}\end{array}$ & $\begin{array}{c}0.100 \\
(2.36)^{* *}\end{array}$ & $\begin{array}{l}0.003 \\
(0.09)\end{array}$ & $\begin{array}{c}-0.008 \\
(0.21)\end{array}$ & $\begin{array}{l}0.020 \\
(0.73)\end{array}$ & $\begin{array}{l}0.021 \\
(0.74)\end{array}$ & $\begin{array}{l}0.021 \\
(0.75)\end{array}$ & $\begin{array}{l}0.021 \\
(0.74)\end{array}$ \\
\hline Small national firm & $\begin{array}{l}0.006 \\
(0.13)\end{array}$ & $\begin{array}{l}0.018 \\
(0.38)\end{array}$ & $\begin{array}{l}-0.012 \\
(0.26)\end{array}$ & $\begin{array}{l}0.002 \\
(0.05)\end{array}$ & $\begin{array}{l}0.009 \\
(0.28)\end{array}$ & $\begin{array}{l}0.014 \\
(0.44)\end{array}$ & $\begin{array}{l}0.009 \\
(0.28)\end{array}$ & $\begin{array}{l}0.014 \\
(0.46)\end{array}$ \\
\hline Had R\&D lab & $\begin{array}{c}0.135 \\
(3.41)^{* * *}\end{array}$ & $\begin{array}{c}0.119 \\
(2.98)^{* * *}\end{array}$ & $\begin{array}{c}0.238 \\
(6.23)^{* * *}\end{array}$ & $\begin{array}{c}0.234 \\
(6.06)^{* * *}\end{array}$ & $\begin{array}{l}0.017 \\
(0.63)\end{array}$ & $\begin{array}{l}0.014 \\
(0.54)\end{array}$ & $\begin{array}{l}0.021 \\
(0.79)\end{array}$ & $\begin{array}{l}0.019 \\
(0.70)\end{array}$ \\
\hline Patentee was principal & $\begin{array}{c}-0.018 \\
(0.45)\end{array}$ & $\begin{array}{r}-0.012 \\
(0.29)\end{array}$ & $\begin{array}{r}-0.057 \\
(1.49)\end{array}$ & $\begin{array}{r}-0.045 \\
(1.14)\end{array}$ & $\begin{array}{l}0.028 \\
(1.04)\end{array}$ & $\begin{array}{l}0.029 \\
(1.06)\end{array}$ & $\begin{array}{l}0.027 \\
(1.00)\end{array}$ & $\begin{array}{l}0.028 \\
(1.04)\end{array}$ \\
\hline West & & $\begin{array}{c}-0.278 \\
(3.54)^{* * *}\end{array}$ & & $\begin{array}{l}0.104 \\
(1.43)\end{array}$ & & $\begin{array}{c}-0.011 \\
(0.23)\end{array}$ & & $\begin{array}{r}-0.007 \\
(0.14)\end{array}$ \\
\hline West North Central & & $\begin{array}{c}-0.054 \\
(0.68)\end{array}$ & & $\begin{array}{c}-0.172 \\
(2.42)^{* *}\end{array}$ & & $\begin{array}{l}-0.028 \\
(0.55)\end{array}$ & & $\begin{array}{c}-0.032 \\
(0.64)\end{array}$ \\
\hline East North Central & & $\begin{array}{l}-0.067 \\
(1.87)^{*}\end{array}$ & & $\begin{array}{c}-0.095 \\
(3.05) * * *\end{array}$ & & $\begin{array}{l}-0.017 \\
(0.76)\end{array}$ & & $\begin{array}{l}-0.019 \\
(0.86)\end{array}$ \\
\hline New England & & $\begin{array}{c}-0.290 \\
(5.97)^{* * *}\end{array}$ & & $\begin{array}{c}-0.113 \\
(2.74)^{* * *}\end{array}$ & & $\begin{array}{l}-0.028 \\
(0.95)\end{array}$ & & $\begin{array}{r}-0.029 \\
(1.01)\end{array}$ \\
\hline South Atlantic & & $\begin{array}{c}-0.126 \\
(1.38)\end{array}$ & & $\begin{array}{c}-0.035 \\
(0.43)\end{array}$ & & $\begin{array}{c}-0.002 \\
(0.03)\end{array}$ & & $\begin{array}{l}-0.001 \\
(0.01)\end{array}$ \\
\hline Other South & & $\begin{array}{l}-0.165 \\
(1.54)\end{array}$ & & $\begin{array}{c}-0.208 \\
(2.24)^{* *}\end{array}$ & & $\begin{array}{l}0.053 \\
(0.75)\end{array}$ & & $\begin{array}{l}0.048 \\
(0.68)\end{array}$ \\
\hline Observations & 1,124 & 1,124 & 1,124 & 1,124 & 1,124 & 1,124 & 1,124 & 1,124 \\
\hline
\end{tabular}

* significant at $10 \%$; ** significant at $5 \%$; *** significant at $1 \%$

Notes and Sources: The absolute value of $\mathrm{z}$ statistics are in parentheses. The estimates are probits, and the reported figures are marginal effects. Observations are patents in the 1928-29 cross section that were assigned to companies. For definitions of the variables, see Tables 1, 2, and 4. 
Table 9: Distribution of Patents by Companies’ Access to Equity Markets in 1929

\begin{tabular}{|c|c|c|c|c|c|c|c|c|c|}
\hline $\begin{array}{l}\text { Exchanges where the firm's } \\
\text { equities traded in } 1929\end{array}$ & $\begin{array}{c}\text { No. of } \\
\text { patents/ } \\
\text { Share of } \\
\text { Patents }\end{array}$ & \begin{tabular}{|c} 
Patents \\
assigned to \\
firms with \\
assets \\
$>=\$ 10$ \\
million \\
\end{tabular} & $\begin{array}{c}\text { Patents } \\
\text { assigned to } \\
\text { firms with } \\
\text { assets } \\
<\$ 10 \\
\text { million } \\
\end{array}$ & \begin{tabular}{|l} 
\\
Patents \\
assigned to \\
firms with \\
R\&D labs
\end{tabular} & \begin{tabular}{|c} 
Patents \\
assigned to \\
firms \\
with \\
inventor \\
principals
\end{tabular} & $\begin{array}{c}\text { Patents } \\
\text { assigned to } \\
\text { firms } \\
\text { without } \\
\text { inventor } \\
\text { principals }\end{array}$ & \begin{tabular}{|c} 
Patents \\
that were \\
cited in \\
$1995-2002$
\end{tabular} & $\begin{array}{c}\text { Patents } \\
\text { that were } \\
\text { high-tech1 }\end{array}$ & $\begin{array}{c}\text { Patents } \\
\text { that were } \\
\text { high-tech2 }\end{array}$ \\
\hline \multicolumn{10}{|c|}{ Panel A: Row percentages of patents } \\
\hline NYSE and regional exchanges & 201 & 98.5 & 1.0 & 92.5 & 3.5 & 96.5 & 22.4 & 89.1 & 60.7 \\
\hline NYSE only & 137 & 94.9 & 5.1 & 65.7 & 5.1 & 94.9 & 31.4 & 69.3 & 24.1 \\
\hline Secondary NY and regional & 63 & 79.4 & 20.6 & 63.5 & 11.1 & 88.9 & 15.9 & 52.4 & 17.5 \\
\hline Secondary NY exchanges only & 58 & 60.3 & 39.7 & 55.2 & 12.1 & 87.9 & 37.9 & 56.9 & 34.5 \\
\hline Regional exchanges only & 41 & 31.7 & 68.3 & 46.3 & 24.4 & 75.6 & 29.3 & 70.7 & 22.0 \\
\hline Unknown & 121 & 35.5 & 62.0 & 40.5 & 23.1 & 76.9 & 31.4 & 45.5 & 22.3 \\
\hline All Assignees found in Moody's & 621 & 75.5 & 23.8 & 67.0 & 10.6 & 89.4 & 27.4 & 68.3 & 35.7 \\
\hline Assignees not found in Moody's & 503 & n.a. & n.a. & 8.5 & 25.8 & 74.2 & 32.0 & 51.5 & 20.9 \\
\hline \multicolumn{10}{|c|}{ Panel B: Column percentages of patents } \\
\hline NYSE and regional exchanges & 17.9 & 42.2 & 1.4 & 40.5 & 3.6 & 20.9 & 13.6 & 26.2 & 37.3 \\
\hline NYSE only & 12.2 & 27.7 & 4.7 & 19.6 & 3.6 & 14.0 & 13.0 & 13.9 & 10.1 \\
\hline Secondary NY and regional & 5.6 & 10.7 & 8.8 & 8.7 & 3.6 & 6.0 & 3.0 & 4.8 & 3.4 \\
\hline Secondary NY exchanges only & 5.2 & 7.5 & 15.5 & 7.0 & 3.6 & 5.5 & 6.6 & 4.8 & 6.1 \\
\hline Regional exchanges only & 3.6 & 2.8 & 18.9 & 4.1 & 5.1 & 3.3 & 3.6 & 4.2 & 2.8 \\
\hline Unknown & 10.8 & 9.2 & 50.7 & 10.7 & 14.3 & 10.0 & 11.5 & 8.1 & 8.3 \\
\hline All assignees found in Moody's & 55.2 & 100.0 & 100.0 & 90.6 & 33.7 & 59.8 & 51.4 & 62.1 & 67.9 \\
\hline Assignees not found in Moody's & 44.8 & 0.0 & 0.0 & 9.4 & 66.3 & 40.2 & 48.6 & 37.9 & 32.1 \\
\hline
\end{tabular}


Notes and Sources: The table includes patents in the 1928-29 cross section that were assigned to companies. Information on the markets where the securities of the assignee companies traded comes from Moody's Manual of Investments for 1929. The category "unknown" includes companies which were covered by Moody's but for which the report did not include information on where the equities traded. The stock of these companies was probably either closely held or traded privately. If the assignee was a subsidiary of a larger company, wherever possible we reported the information for the parent company. The variable "patents assigned to firms with inventor principals" includes firms that bore the patentees' surnames, as well as firms for which we know the patentee was an officer, director, or proprietor. All remaining firms are included in "patents assigned to firms without inventor principals." For definitions of the other variables, see Tables 1 and 2. 
Table 10: Companies’ Access to Equity Markets in 1929

\begin{tabular}{|c|c|c|c|c|c|c|}
\hline $\begin{array}{l}\text { Exchanges where the firm's } \\
\text { equities traded in } 1929\end{array}$ & $\begin{array}{c}\text { Number of } \\
\text { firms/Share } \\
\text { of firms }\end{array}$ & $\begin{array}{c}\text { Assignee } \\
\text { firms with } \\
\text { assets ? \$10 } \\
\text { million }\end{array}$ & $\begin{array}{c}\text { Assignee } \\
\text { firms with } \\
\text { assets }<\$ 10 \\
\text { million } \\
\end{array}$ & $\begin{array}{l}\text { Assignee } \\
\text { firms with } \\
\text { R\&Dlabs }\end{array}$ & $\begin{array}{l}\text { Assignee } \\
\text { firms with } \\
\text { inventor } \\
\text { principals }\end{array}$ & $\begin{array}{c}\text { Assignee } \\
\text { firms without } \\
\text { inventor } \\
\text { principals }\end{array}$ \\
\hline \multicolumn{7}{|c|}{ Panel A: Row percentages of firms } \\
\hline NYSE and regional exchanges & 45 & 93.3 & 4.4 & 73.3 & 6.7 & 93.3 \\
\hline NYSE only & 75 & 93.3 & 6.7 & 49.3 & 8.0 & 92.0 \\
\hline Secondary NY and regional & 29 & 65.5 & 34.5 & 58.6 & 13.8 & 86.2 \\
\hline Secondary NY exchanges only & 42 & 54.8 & 45.2 & 59.5 & 9.5 & 90.5 \\
\hline Regional exchanges only & 32 & 21.9 & 78.1 & 37.5 & 28.1 & 71.9 \\
\hline Unknown & 93 & 24.7 & 72.0 & 32.3 & 25.8 & 74.2 \\
\hline All Assignees found in Moody’s & 316 & 58.2 & 40.5 & 48.7 & 15.8 & 84.2 \\
\hline Assignees not found in Moody’s & 471 & n.a. & n.a. & 7.4 & 27.2 & 72.8 \\
\hline \multicolumn{7}{|c|}{ Panel B: Column percentages of firms } \\
\hline NYSE and regional exchanges & 5.7 & 22.8 & 1.6 & 17.5 & 1.7 & 6.9 \\
\hline NYSE only & 9.5 & 38.0 & 3.9 & 19.6 & 3.4 & 11.3 \\
\hline Secondary NY and regional & 3.7 & 10.3 & 7.8 & 9.0 & 2.2 & 4.1 \\
\hline Secondary NY exchanges only & 5.3 & 12.5 & 14.8 & 13.2 & 2.2 & 6.3 \\
\hline Regional exchanges only & 4.1 & 3.8 & 19.5 & 6.3 & 5.1 & 3.8 \\
\hline Unknown & 11.8 & 12.5 & 52.3 & 15.9 & 13.5 & 11.3 \\
\hline All Assignees found in Moody's & 40.2 & 100.0 & 100.0 & 81.5 & 28.1 & 43.8 \\
\hline Assignees not found in Moody's & 59.8 & n.a. & n.a. & 18.5 & 71.9 & 56.3 \\
\hline
\end{tabular}

Notes and Sources: See Tables 1, 2, and 9. 
Table 11: Earlier Trading Histories of Assignee Companies Found in Moody’s in 1929

\begin{tabular}{|c|c|c|c|c|c|c|c|c|c|c|c|c|c|c|}
\hline & \multicolumn{2}{|c|}{$\begin{array}{l}\text { NYSE and } \\
\text { regional } \\
\text { exchanges }\end{array}$} & \multicolumn{2}{|c|}{ NYSE only } & \multicolumn{2}{|c|}{$\begin{array}{l}\text { Secondary } \\
\text { NY and } \\
\text { regional } \\
\text { exchanges }\end{array}$} & \multicolumn{2}{|c|}{$\begin{array}{c}\text { Secondary } \\
\text { NY exchanges } \\
\text { only }\end{array}$} & \multicolumn{2}{|c|}{$\begin{array}{l}\text { Regional } \\
\text { exchanges } \\
\text { only }\end{array}$} & \multicolumn{2}{|c|}{ Unknown } & \multicolumn{2}{|c|}{$\begin{array}{c}\text { No financial } \\
\text { report }\end{array}$} \\
\hline & 1924 & 1912 & 1924 & 1912 & 1924 & 1912 & 1924 & 1912 & 1924 & 1912 & 1924 & 1912 & 1924 & 1912 \\
\hline \multicolumn{15}{|c|}{ Panel A: Row percentages of firms } \\
\hline NYSE and regional exchanges & 55.6 & 15.6 & 2.2 & 2.2 & 6.7 & 0.0 & 0.0 & 0.0 & 6.7 & 15.6 & 6.7 & 17.8 & 22.2 & 48.9 \\
\hline NYSE only & 4.0 & 4.0 & 37.3 & 12.0 & 0.0 & 0.0 & 6.7 & 4.0 & 2.7 & 2.7 & 20.0 & 21.3 & 29.3 & 56.0 \\
\hline Secondary NY and regional exchanges & 6.9 & 0.0 & 0.0 & 0.0 & 10.3 & 0.0 & 6.9 & 0.0 & 31.0 & 17.2 & 27.6 & 37.9 & 17.2 & 44.8 \\
\hline Secondary NY exchanges only & 4.8 & 0.0 & 0.0 & 2.4 & 2.4 & 0.0 & 23.8 & 0.0 & 0.0 & 2.4 & 42.9 & 38.1 & 26.2 & 57.1 \\
\hline Regional exchanges only & 0.0 & 0.0 & 0.0 & 0.0 & 0.0 & 0.0 & 0.0 & 0.0 & 31.3 & 9.4 & 25.0 & 21.9 & 43.8 & 68.8 \\
\hline Unknown & 0.0 & 0.0 & 0.0 & 0.0 & 0.0 & 0.0 & 0.0 & 0.0 & 2.2 & 3.2 & 57.0 & 19.4 & 40.9 & 77.4 \\
\hline All categories of equities & 10.1 & 3.2 & 9.2 & 3.5 & 2.2 & 0.0 & 5.4 & 0.9 & 8.2 & 6.6 & 33.2 & 24.1 & 31.6 & 61.7 \\
\hline \multicolumn{15}{|c|}{ Panel B: Column percentages of firms } \\
\hline NYSE and regional exchanges & 78.1 & 70.0 & 3.4 & 9.1 & 42.9 & n.a. & 0.0 & 0.0 & 11.5 & 33.3 & 2.9 & 10.5 & 10.0 & 11.3 \\
\hline NYSE only & 9.4 & 30.0 & 96.6 & 81.8 & 0.0 & n.a. & 29.4 & 100.0 & 7.7 & 9.5 & 14.3 & 21.1 & 22.0 & 21.5 \\
\hline Secondary NY and regional exchanges & 6.3 & 0.0 & 0.0 & 0.0 & 42.9 & n.a. & 11.8 & 0.0 & 34.6 & 23.8 & 7.6 & 14.5 & 5.0 & 6.7 \\
\hline Secondary NY exchanges only & 6.3 & 0.0 & 0.0 & 9.1 & 14.3 & n.a. & 58.8 & 0.0 & 0.0 & 4.8 & 17.1 & 21.1 & 11.0 & 12.3 \\
\hline Regional exchanges only & 0.0 & 0.0 & 0.0 & 0.0 & 0.0 & n.a. & 0.0 & 0.0 & 38.5 & 14.3 & 7.6 & 9.2 & 14.0 & 11.3 \\
\hline Unknown & 0.0 & 0.0 & 0.0 & 0.0 & 0.0 & n.a. & 0.0 & 0.0 & 7.7 & 14.3 & 50.5 & 23.7 & 38.0 & 36.9 \\
\hline All categories of equities & 100.0 & 100.0 & 100.0 & 100.0 & 100.0 & n.a. & 100.0 & 100.0 & 100.0 & 100.0 & 100.0 & 100.0 & 100.0 & 100.0 \\
\hline
\end{tabular}

Notes and Sources: The table includes firms assigned patents in the 1928-29 for which there were reports in Moody's for 1929.

Trading information comes from Moody's Manual of Investments for 1924 and 1929 and Poor's Manual of Industrials for 1912. 
Table 12: Effects of the Great Depression by Type of Firm and Region

\begin{tabular}{|c|c|c|c|c|c|c|c|c|}
\hline & (1) & (2) & (3) & (4) & \multicolumn{4}{|c|}{$\begin{array}{l}\text { (5) (6) } \\
\text { Bankrupt, in reorganization, dropped from } \\
\text { Moody's, or access to financial markets } \\
\text { deteriorated }\end{array}$} \\
\hline & \multicolumn{4}{|c|}{$\begin{array}{l}\text { Bankrupt, in reorganization, or dropped from } \\
\text { Moody’s }\end{array}$} & \multicolumn{4}{|c|}{$\begin{array}{c}\text { Bankrupt, in reorganization, dropped from } \\
\text { Moody’s, or access to financial markets } \\
\text { deteriorated }\end{array}$} \\
\hline & \multicolumn{2}{|c|}{ Using high-tech1 } & \multicolumn{2}{|c|}{ Using high-tech2 } & \multicolumn{2}{|c|}{ Using high-tech1 } & \multicolumn{2}{|c|}{ Using high-tech2 } \\
\hline High-tech patent & $\begin{array}{l}0.020 \\
(0.66)\end{array}$ & $\begin{array}{l}0.022 \\
(0.74)\end{array}$ & $\begin{array}{l}0.025 \\
(0.79)\end{array}$ & $\begin{array}{l}0.031 \\
(0.96)\end{array}$ & $\begin{array}{c}-0.103 \\
(2.76)^{* * *}\end{array}$ & $\begin{array}{c}-0.089 \\
(2.37)^{* *}\end{array}$ & $\begin{array}{c}-0.029 \\
(0.77)\end{array}$ & $\begin{array}{r}-0.017 \\
(0.44)\end{array}$ \\
\hline Large firm & $\begin{array}{c}-0.185 \\
(4.79)^{* * *}\end{array}$ & $\begin{array}{c}-0.177 \\
(4.63)^{* * *}\end{array}$ & $\begin{array}{c}-0.184 \\
(4.78)^{* * *}\end{array}$ & $\begin{array}{c}-0.175 \\
(4.61)^{* * *}\end{array}$ & $\begin{array}{c}-0.220 \\
(4.85)^{* * *}\end{array}$ & $\begin{array}{c}-0.205 \\
(4.53) * * *\end{array}$ & $\begin{array}{c}-0.228 \\
(4.99)^{* * *}\end{array}$ & $\begin{array}{c}-0.210 \\
(4.60)^{* * *}\end{array}$ \\
\hline Had R\&D lab & $\begin{array}{c}-0.210 \\
(5.88)^{* * *}\end{array}$ & $\begin{array}{c}-0.200 \\
(5.66)^{* * *}\end{array}$ & $\begin{array}{c}-0.215 \\
(5.85)^{* * *}\end{array}$ & $\begin{array}{c}-0.205 \\
(5.66)^{* * *}\end{array}$ & $\begin{array}{c}-0.154 \\
(3.81)^{* * *}\end{array}$ & $\begin{array}{c}-0.142 \\
(3.52)^{* * *}\end{array}$ & $\begin{array}{c}-0.162 \\
(3.91)^{* * *}\end{array}$ & $\begin{array}{c}-0.150 \\
(3.61)^{* * *}\end{array}$ \\
\hline Patentee was principal & $\begin{array}{l}0.003 \\
(0.06)\end{array}$ & $\begin{array}{r}-0.005 \\
(0.12)\end{array}$ & $\begin{array}{l}0.003 \\
(0.06)\end{array}$ & $\begin{array}{c}-0.005 \\
(0.14)\end{array}$ & $\begin{array}{l}0.078 \\
(1.39)\end{array}$ & $\begin{array}{l}0.062 \\
(1.12)\end{array}$ & $\begin{array}{l}0.075 \\
(1.35)\end{array}$ & $\begin{array}{l}0.064 \\
(1.14)\end{array}$ \\
\hline West & & $\begin{array}{c}0.233 \\
(1.97)^{* *}\end{array}$ & & $\begin{array}{c}0.221 \\
(1.91)^{*}\end{array}$ & & $\begin{array}{l}0.192 \\
(1.45)\end{array}$ & & $\begin{array}{l}0.205 \\
(1.51)\end{array}$ \\
\hline West North Central & & $\begin{array}{c}0.366 \\
(3.07)^{* * *}\end{array}$ & & $\begin{array}{c}0.365 \\
(3.07)^{* * *}\end{array}$ & & $\begin{array}{c}0.431 \\
3.25)^{* * *}\end{array}$ & & $\begin{array}{c}0.454 \\
(3.38)^{* * *}\end{array}$ \\
\hline East North Central & & $\begin{array}{c}0.065 \\
(1.90)^{*}\end{array}$ & & $\begin{array}{c}0.067 \\
(1.96)^{*}\end{array}$ & & $\begin{array}{c}0.085 \\
2.04)^{* *}\end{array}$ & & $\begin{array}{c}0.083 \\
(1.99)^{* *}\end{array}$ \\
\hline New England & & $\begin{array}{c}-0.012 \\
(0.28)\end{array}$ & & $\begin{array}{l}-0.014 \\
(0.34)\end{array}$ & & $\begin{array}{l}0.081 \\
(1.45)\end{array}$ & & $\begin{array}{c}0.105 \\
(1.87)^{*}\end{array}$ \\
\hline South Atlantic & & $\begin{array}{l}0.071 \\
(0.58)\end{array}$ & & $\begin{array}{l}0.061 \\
(0.50)\end{array}$ & & $\begin{array}{l}-0.013 \\
(0.09)\end{array}$ & & $\begin{array}{l}-0.011 \\
(0.07)\end{array}$ \\
\hline Other South & & $\begin{array}{c}0.464 \\
(2.00)^{* *}\end{array}$ & & $\begin{array}{c}0.463 \\
(2.01)^{* *}\end{array}$ & & $\begin{array}{l}0.362 \\
(1.48)\end{array}$ & & $\begin{array}{l}0.381 \\
(1.54)\end{array}$ \\
\hline Observations & 621 & 621 & 621 & 621 & 621 & 621 & 621 & 621 \\
\hline
\end{tabular}

* significant at 10\%; ** significant at 5\%; *** significant at $1 \%$

Notes and Sources: The absolute value of $\mathrm{z}$ statistics are in parentheses. The estimates are probits, and the reported figures are the marginal effects. The observations are patents in the 1928-29 cross section that were assigned to companies for which there were reports in Moody's for 1929. Because our observations are patents, the estimations are effectively weighted by the number of patents each company was assigned. In the first four columns, the dependent variable is a dummy which takes a value of one if Moody's no longer published a report on the firm obtaining the patent or if the report indicated that the firm was in bankruptcy or being reorganized. Seventeen percent of patents were assigned to firms classified as distressed by this definition. In the second four columns, the dependent variable is a dummy that aims to capture deterioration in an assignee's access to financial markets using the following coding scheme: Firms that were listed on the NYSE were coded 5; those listed on both a regional market and a secondary New York market, 4; those listed on either a regional market or a secondary New York market but not both, 3; those for which no listing information was given, 2; and those without any report in Moody's, 1 . The dependent variable obtained a value of 1 if the firm obtaining the patent had a numerical code that was lower in 1935 than in 1929 or if the firm was in bankruptcy or reorganization, and a 0 in all other cases. Twenty-four percent of patents were assigned to firms classified as distressed by this second definition. For definitions of the independent variables, see Tables 1, 2, 4, and 8. 
Figure 1. Patenting Rates by Region

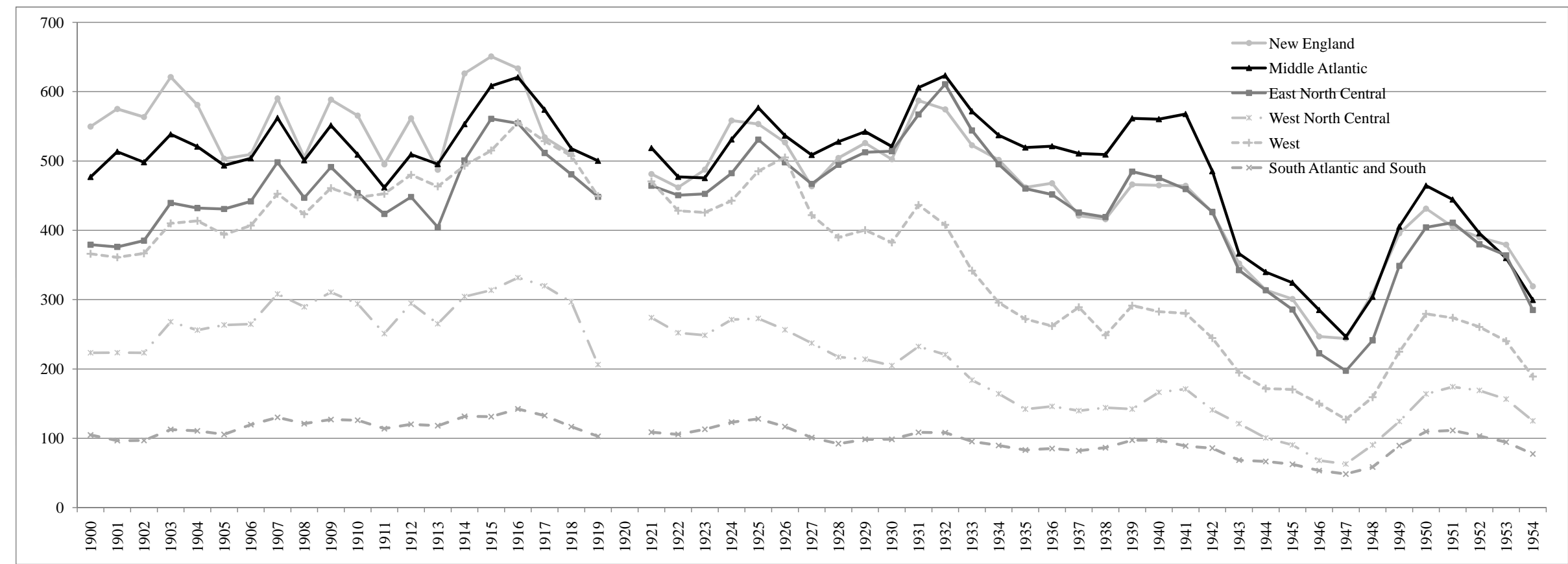

Notes and Sources : Patent rates are number of patents per million residents of the region. Patent counts come from U.S.

Commissioner of Patents, Annual Reports , 1900-1925, 1946, and 1955. Population figures are from U.S. Census Bureau,

"Demographic Trends in the 20th Century," Census 2000 Special Reports, Series CENSR-4,

http://www.census.gov/prod/2002pubs/censr-4.pdf (released 2002). 